\title{
Lazaroa
}

ISSN-e 1988-3307

\section{Syntaxonomic synopsis of the forest and tall scrub vegetation of Northern Algeria}

\author{
Rachid Meddour ${ }^{1}$, Ouahiba Meddour-Sahar ${ }^{1}$, Lamri Zeraia $^{2}$ \& Ladislav Mucina ${ }^{3,4}$
}

Received: 29 July 2016 / Accepted: 16 October 2017

\begin{abstract}
This paper presents the first syntaxonomic conspectus of the forest and scrub communities of Northern Algeria. The communities belong mainly to the zonal classes such as the Quercetea ilicis, Quercetea pubescentis and Junipero-Pinetea sylvestris (new to Algeria). The Cytisetea scopario-striati and Nerio-Tamaricetea are considered intrazonal within the Mediterranean zone, while the Crataego-Prunetea considered intrazonal within the Temperate zone. The azonal vegetation is represented by four classes: Alno glutinosae-Populetea albae, Salicetea purpureae, Alnetea glutinosae, and Franguletea (the latter being recognised in Algeria for the first time). We attempted to include all known syntaxa as featured in both regular and grey literature; many of those still await effective publication or formal validation. The paper also presents formal descriptions (and/or validations) of one new order, 12 new alliances, and 15 new associations.
\end{abstract}

Keywords: Algeria, forest vegetation, scrub vegetation, phytosociology, syntaxonomy.

[es] Sinopsis sintaxonómica de los bosques y matorrales de alta talla de la vegetación del norte de Argelia

Resumen. Este trabajo presenta el primer esquema sintaxonómico de las comunidades forestales y de matorrales de alta talla del norte de Argelia. Las comunidades pertenecen principalmente a las clases zonales Quercetea ilicis, Quercetea pubescentis y Junipero-Pinetea sylvestris (nuevas en Argelia). Cytisetea scopario-striati y Nerio-Tamaricetea se consideran intrazonales dentro de la zona mediterránea, y Crataego-Prunetea intrazonal dentro de la zona templada. La vegetación azonal está representada por cuatro clases: Alno glutinosae-Populetea albae, Salicetea purpureae, Alnetea glutinosae y Franguletea (esta última se reconoce en Argelia por primera vez). Intentamos incluir toda la sintaxis conocida en publicaciones válidas e inéditas; por ello, muchos nombres todavía esperan una publicación efectiva o una validación formal. El documento también presenta descripciones formales (y / o validaciones) de un nuevo orden, 12 nuevas alianzas y 15 nuevas asociaciones.

Palabras clave: Argelia; vegetación forestal; vegetación arbustiva; fitosociología; sintaxonomía.

\section{Introduction}

Algerian forests cover about 4.11 million of hectares that represents only $1.76 \%$ for the entire national territory, and $16.4 \%$ for its northern regions (Djema \& Messaoudène, 2009). These forests are limited to humid, subhumid and semi-arid bioclimatic zones, and are mostly distributed in the mountainous regions of
Tellian and Saharan Atlas in Northern Algeria. The elevational span of the forest occurrence is broad and covering all belts between the thermomediterranean and the oromediterranean altitudes (sensu Quézel \& Médail, 2003a).

Phytosociological studies in Algeria date back to the 1950s. The syntaxonomy of forest (and tall scrub) vegetation types, such as forest, scrub and macchia, was earlier studied by for-

\footnotetext{
Faculté des Sciences Biologiques et Agronomiques, Université Mouloud Mammeri, B.P. 17 R.P., 15000, Tizi Ouzou, Algérie. Email: rachid_meddour@yahoo.fr

9 rue des communautés, F-34080 Montpellier, France.

3 Iluka Chair in Vegetation Science \& Biogeography, School of Biological Sciences, The University of Western Australia, 35 Stirling Hwy, Crawley WA 6009, Perth, Australia.

4 Department of Geography \& Environmental Studies, Stellenbosch University, Private Bag X1, Matieland 7602, Stellenbosch, South Africa.
} 
eign researchers (e.g. Quézel, 1956; Zaffran, 1960; Nègre, 1964). Although these authors have described many syntaxonomic units, the general syntaxonomic framework as used in North Africa, and in Algeria in particular, relies heavily on studies of the Western Mediterranean vegetation (e.g. Loisel, 1971; Barbero et al., 1974, 1981; Barbero \& Quézel, 1975; Rivas-Martínez, 1975; Rivas-Martínez \& Rivas Goday, 1975; Quézel \& Barbero, 1981, 1986, 1989; Rivas-Martínez et al., 1986, 1999, 2001, 2002, 2011; de Foucault et al., 2012).

Despite the obvious important ecological services and conservation value, the focused attention, the forest and scrub vegetation of Algeria has been receiving only since the $80^{\text {th }}$ of the past century, especially by researchers using the Braun-Blanquet (1964) approach. These studies accumulated valuable phytosociological data on almost all forest vegetation types, such as sclerophyllous evergreen forests, deciduous broadleaved forests, coniferous forests, and riparian forests (Guinochet, 1980; Zeraia, 1981; Abdessemed, 1981; Dahmani, 1984, 1997; Bensettiti, 1985, 1995; Toubal, 1986; Aimé et al., 1986; Khelifi, 1987, 2008; Sadki, 1988; Hadjadj-Aoul, 1988, 1995; Wojterski, 1988; Quézel \& Barbero, 1989; Géhu et al., 1992, 1994a, 1994b; Meddour, 1993, 1994a, 1994b, 1998, 1999, 2002, 2010; Yahi, 1995, 2007; Géhu \& Sadki, 1996; Bensettiti \& Lacoste, 1999; Hadjadj-Aoul \& Loisel, 1999; Laribi, 2000; Gharzouli, 1989, 2007; Dahmani-Megrerouche \& Loisel, 2003; Laribi et al., 2008; Meddour et al., 2010; Siab-Farsi et al., 2014).

The first syntaxonomic synopsis of the forest and scrub plant communities of Algeria presented 6 classes, 8 orders, 22 alliances and 70 associations and/or rank-less plant communities (Meddour \& Géhu, 1998). A synthesis of the forest communities by Djebaïli (1994) listed only 20 associations, belonging to 2 classes, 2 orders and 5 alliances. Later, Dahmani-Megrerouche et al. (2014) summarised the syntaxonomy of forest vegetation in Algeria into merely 2 classes, 3 orders, 10 alliances and 28 associations.

In this paper, we present a synopsis of the Northern Algerian forest and scrub syntaxa described according to the Braun-Blanquet approach. The aim of this conspectus is formulation of a backbone of syntaxonomic system of this vegetation that would serve syntaxonomic and nomenclatural revisions in future. We also summarise the major source of the phytosociological data to assist such revisions.

\section{Material and methods}

We conducted a detailed bibliographic research on published studies (about 50 published papers and 40 unpublished theses) describing Algerian forest vegetation.

In this synopsis, we list all forest and scrub-dominated vegetation types (syntaxa) described by Braun-Blanquet approach in Algeria in the course of the past 60 years (1956-2016). Only the syntaxa documented by phytosociological relevés are considered here.

Intentionally, we are not covering number of published subassociations and suballiances since their syntaxonomic value still should clarified. At this stage, we refrain from nomenclatural and syntaxonomic revision of the association (and subassociations). This critical revision will be attempted elsewhere. We provide (presumably) correct name for each syntaxon, synonyms as known from the Algerian literature, lists of author(s) who have studied the given syntaxon in Algeria, and all other related references that include pertinent phytosociological relevés. We refer to Meddour (2010) for the synecological descriptions, distribution, and diagnostic species lists for each association. The concepts and nomenclature of the classes and most of the follows Mucina et al. (2016) and we applied the naming rules of the ICPN (Weber et al., 2000) to other high-rank syntaxa not covered by the European vegetation system (Mucina et al., 2016). In synonymy of some associations we also cite the article of the ICPN, according to which the synonym is deemed invalid or illegitimate. Some syntaxonomic and nomenclatural concepts of the orders and alliances, as currently used in Algerian phytosociological literature, are however still subject to future revisions.

\section{Results}

We list 129 associations (including 15 rankless plant communities) classified into 10 classes, 12 orders (1 new), and 34 alliances (12 new). Two orders and 18 alliances (marked with an asterisk) are endemic to North Africa. 


\section{SYNTAXONOMIC SURVEY OF CLASSES}

The classification of the classes within the zonal-intrazonal-azonal system follows Mucina et al. (2016).

\section{Zonal mediterranean woodlands and scrub}

Quercetea ilicis Braun-Blanquet ex A. de Bolòs \& O. de Bolòs in A. Bolòs y Vayreda 1950

\section{Zonal submediterranean woodlands and scrub}

Junipero-Pinetea sylvestris Rivas-Martínez 1965 nom. invers. propos.

Quercetea pubescentis Doing-Kraft ex Scamoni \& Passarge 1959

\section{Intrazonal Mediterranean woodlands and scrub}

Cytisetea scopario-striati Rivas-Martínez 1974 Nerio-Tamaricetea Braun-Blanquet \& O. de Bolòs 1958

\section{Intrazonal Temperate woodlands and scrub}

Crataego-Prunetea Tüxen 1962 nom. conserv. propos.

\section{Azonal temperate woodlands and scrub}

Alno glutinosae-Populetea albae P. Fukarek \& Fabijanić 1968

Salicetea purpureae Moor 1958

Alnetea glutinosae Braun-Blanquet \& Tüxen ex Westhoff, Dijk \& Passchier 1946

Franguletea Doing ex Westhoff in Westhoff \& Den Held 1969

\section{ANNOTATED SYNTAXONOMIC SYSTEM}

Quercetea ilicis Braun-Blanquet ex A. de Bolòs \& O. de Bolòs in A. Bolòs y Vayreda 1950 Thermo-mesomediterranean pine and oak forests and associated macchia of the Mediterranean

- Pistacio lentisci-Rhamnetea alaterni Julve 1992 (phantom)

- Pistacio lentisci-Rhamnetea alaterni Julve 1993 (syntax. syn.)

Syntaxonomic and nomenclatural notes: De Foucault (1993) have 'described' a series of 'Les synusies arborescentes' under the following names:
'Pino halepensis-Quercetea ilicis (Br.-B1. 1947) de Fouc. et Julve 1991'

'Quercetalia rotundifolio-ilicis de Fouc. et Julve 1991 '

'Querco rotundifoliae-Cedrion atlanticae all. nov.'

'Querco rotundifoliae-Cedretum atlanticae (Barbero et al. 1981) nov.'

'Aceri monspessulani-Cedretum atlanticae (Br.B1. et Maire 1924) nov.'

'Aceri granatense-Abietetum maroccanae (Barbero et al.) nov.'

'Quercion rotundifolio-suberis (Barbero et al. 1981) all. nov.'

'Pino halepensis-Tetraclinetalia articulatae ord. nov. prov.'

'Tetraclinion articulatae all. nov.'

Since all are synusial units of vegetation of vascular plants, and these are not subject to the ICPN (Definition I, art. 3d), and therefore not considered here either as candidates for valid names or synonyms.

Quercetalia ilicis Braun-Blanquet ex Molinier 1934

Evergreen and semi-deciduous thermo-to supramediterranean oak and relict laurel forests of the Central and Western Mediterranean

- Quercetalia atlanticae Bensettiti \& Lacoste 1999 nom. inval. (Art. 8)

Oleo sylvestris-Quercion rotundifoliae Barbero, Quézel \& Rivas-Martínez in Rivas-Martínez, Costa \& Izco 1986 nom. invers. propos.

Thermo-mediterranean evergreen oak forests on deep soils in subhumid and humid regions of the Iberian Peninsula and North Africa

Typus: Myrto communis-Quercetum suberis Barbero, Benabid, Quézel \& RivasMartínez in Barbero, Quézel \& RivasMartínez 1981 (Barbero et al., 1981: 319, Table 3, rel. 2)

- Oleo sylvestris-Quercion rotundifoliosuberis Barbero, Quézel \& Rivas-Martínez 1981 nom. inval. (Art. 5)

- 'Querco rotundifoliae-Oleion sylvestris' Barbero, Quézel \& Rivas-Martínez in Rivas-Martínez, Costa \& Izco 1986 (orig. form)

- non Quercion suberis Loisel 1971

Myrto communis-Quercetum suberis Barbero, Benabid, Quézel \& Rivas-Martínez in Barbero, Quézel \& Rivas-Martínez 1981 
Nomenclatural and syntaxonomic notes: Barbero et al. (1981), similarly as with many other new associations in their paper, have placed an asterisk next to the number of a relevé in the header of the table. (In case of the Myrto-Quercetum suberis, the relevé 2 in Tab. 3 in Barbero et al., 1981 carry an asterisk.) This symbol has been used in cases to designate 'type' relevé of a new syntaxon in francophone phytosociological literature in the past and therefore we suggest recognising it as an acceptable indication of the type relevé, rendering the new syntaxa validly published.

Lit.: Zeraia (1981), Toubal (1986), Wojterski (1988), Toubal \& Toubal (1996b), Meddour (2002).

Smilaco mauritanicae-Quercetum rotundifoliae Barbero, Quézel \& RivasMartínez 1981

- 'Smilaci mauritanicae-Quercetum rotundifoliae' Barbero, Quézel \& Rivas-Martínez 1981 (orig. form)

Lit.: Zeraia (1981), Wojterski (1988).

Pistacio terebinthi-Quercetum rotundifoliae Dahmani-Megrerouche \& Loisel 2003 nom. inval. (Art. 5)

- Pistacio terebinthi-Quercetum rotundifoliae Dahmani-Megrerouche 1996 nom. inval. (Art. 2b)

Lit.: Dahmani-Megrerouche (1996a, 1996b, 1997), Dahmani-Megrerouche \& Loisel (2003).

Pistacio lentisci-Quercetum rotundifoliae Dahmani-Megrerouche \& Loisel 2003 nom. inval. (Art. 5)

- Pistacio lentisci-Quercetum rotundifoliae Dahmani-Megrerouche 1996 nom. inval. (Art. 2b)

Lit.: Dahmani-Megrerouche (1996a, 1996b, 1997), Brakchi (1998), Dahmani-Megrerouche \& Loisel (2003), Lemouissi (2014)

\section{Cytiso triflori-Quercetum suberis}

Braun-Blanquet 1953

- 'Cytiseto-Quercetum suberis' BraunBlanquet 1953 (orig. form)

- Cytiso villosi-Quercetum suberis BraunBlanquet 1953 corr. Serra, Loddo \& Bacchetta 2002 (corr. illeg.)
- Cytisovillosi-Quercetumsuberis BraunBlanquet 1953 nom. mut. propos.

Nomenclatural note: In the original diagnosis, Cytisus triflorus is the only Cytisus species listed. Serra et al. (2002) have changed the name using Cytisus villosus as the eponymous. However, this 'correction' has not been explicitly performed in accordance with the ICPN.

Lit.: Quézel (1956), Zeraia (1981), Dahmani (1984), Toubal (1986), Khelifi (1987), Sadki (1988), Wojterski (1988, 1990), Salamani (1990), Khelifi \& Sadki (1995), Toubal \& Toubal (1996b), Meddour (2002, 2010), Iboukassene (2008), Meddour et al. (2010). Figure 2B.

Festuco triflorae-Quercetum suberis Meddour 2010 nom. inval. (Art. 1)

Lit.: Meddour (2010).

Pistacio lentisci-Quercetum suberis Khelifi \& Sadki 1995 nom. inval. (Art. 5)

- Pistacio lentisci-Quercetum suberis Khelifi 1987 nom. inval. (Art. 1)

- 'Forêt de chêne liège à lentisque' (Debazac, 1959)

Lit.: Debazac (1959), Toubal (1986), Khelifi (1987), Khelifi \& Sadki (1995), Meddour (1994a, 2002).

Telino linifoliae-Quercetum suberis Zeraia 1981 nom. inval. (Art. 1)

Syntaxonomic note: This association, recognized in Morocco (Maâmora forest), has been linked to the 'QuercoOleion sylvestris' (Barbero et al., 1981; Benabid \& Fennane, 1994; Benabid, 2000; Fennane, 2003; Aafi, 2007). It is reminiscent of the xero-thermophilous cork-oak forest on siliceous substrates of Provence (Querco suberis-Genistetum linifoliae Loisel 1971), and formerly classified in Algeria as part of the Quercion suberis (Loisel, 1976).

Lit.: Zeraia (1981).

Genisto numidicae-Quercetum suberis Toubal 1998

- Erico scopariae-Quercetum suberis Khelifi 1987 nom. inval. (Art. 1)

Lit.: Khelifi (1987), Khelifi \& Sadki (1995), Toubal (1998). 
Lonicero implexae-Quercion cocciferae all. nova hoc loco*

Thermo-mediterranean kermes oak and forests on deep soils in subhumid regions of Western Algeria

Holotypus (hoc loco): Lonicero implexae-Quercetum cocciferae Nègre 1964 (Nègre, 1964: 30, Table 7)

Diagnostic taxa: Lonicera implexa, Osyris quadripartita, Phillyrea latifolia, Prasium majus, Quercus coccifera

Syntaxonomic note: This new is based on the concept of invalidly published suballiance Oleo sylvestris-Quercenion cocciferae Hadjadj-Aoul \& Loisel 2010 nom. inval. (Art. 5).

Lonicero implexae-Quercetum cocciferae Nègre 1964

Lit.: Nègre (1964), Baumgartner (1966), Wojterski (1988, 1990), Hadjadj-Aoul \& Loisel (1999), Rebbas et al. (2011).

Phillyreo latifoliae-Quercetum cocciferae Quézel, Barbero, Benabid, Loisel \& RivasMartínez 1988

- 'Prasio-Oleetum' O. de Bolòs in O. de Bolòs \& Molinier 1969 (phantom; in Guinochet 1980)

Lit.: Guinochet (1980), Hadjadj-Aoul (1988, 1993), Hadjadj (1991), Meddour (2002).

Oleo sylvestris-Tetraclinetum articulatae Hadjadj-Aoul \& Loisel 1999

- non Oleo salicifoliae-Tetraclinetum articulatae Fennane 1988 nom. inval. (Art. 5) Lit.: Hadjadj-Aoul \& Loisel (1999).

Rusco hypophylli-Tetraclinetum articulatae Hadjadj-Aoul \& Loisel 1999

Lit.: Hadjadj-Aoul \& Loisel (1999).

Osyrido quadripartitae-Quercetum cocciferae Hadjadj-Aoul \& Loisel 1999

Lit.: Hadjadj-Aoul \& Loisel (1999).

Junipero oxycedri-Quercetum cocciferae Hadjadj-Aoul \& Loisel 1999 nom. illeg. (Art. 31)

- non Junipero oxycedri-Quercetum cocciferae (Braun-Blanquet 1924) de Foucault \& Julve 1991

- nonJuniperooxycedri-Quercetum cocciferae Sánchez García, Sánchez Gullón, Linares Perea \& Galán de Mera 2014
Lit.: Hadjadj-Aoul \& Loisel (1999).

Tamo communis-Quercetum cocciferae Hadjadj-Aoul \& Loisel 1999

Lit.: Hadjadj-Aoul \& Loisel (1999).

Tetraclinoarticulatae-Phillyreetum latifoliae Hadjadj-Aoul \& Loisel 1999

Lit.: Hadjadj-Aoul \& Loisel (1999), Medjahdi (2010).

Balansaeo glaberrimae-Quercion rotundifoliae Barbero, Quézel \& Rivas-Martínez ex RivasMartínez et al. 2011*

Meso-supramediterranean evergreen oak forests on deep soils, calcareous and decarbonated soils of North Africa

- Balansaeo glaberrimae-Quercion rotundifoliae Barbero, Quézel \& Rivas-Martínez 1981 nom. inval. (Art. 5)

Balansaeo glaberrimae-Quercetum rotundifoliae Barbero, Quézel \& Rivas-Martínez 1981

- Lino numidici-Teucrietum kabylici Gharzouli 1989 nom. inval. (Art. 1)

Lit.: Gharzouli (1989), Dahmani-Megrerouche (1996a, 1996b, 1997), DahmaniMegrerouche \& Loisel (2003), Meddour (2010), Meddour et al. (2010). Figure 1A.

Phlomido bovei-Quercetum rotundifoliae Zeraia in Meddour 2002 nom. inval. (Art. 2b)

- Phlomidobovei-Quercetumrotundifoliae Zeraia 1981 nom. inval. (Art. 1)

Lit.: Zeraia (1981), Meddour (1994a, 2002). Figure 2A.

Cytiso villosi-Quercetum rotundifoliae Dahmani-Megrerouche \& Loisel 2003 nom. inval. (Art. 5)

- Cytiso triflori-Quercetum rotundifoliae Meddour 1994 nom. inval. (Art. 1)

- Cytiso-Quercetum Dahmani-Megrerouche 1996 nom. inval. (Art. 2b)

Lit.: Wojterski (1988), Meddour (1994a, 2002, 2010), Dahmani-Megrerouche (1996a, 1996b, 1997), Dahmani-Megrerouche \& Loisel (2003), Meddour et al. (2010), Lemouissi (2014).

Festuco triflorae-Quercetum rotundifoliae Dahmani-Megrerouche 1996 nom. inval. (Art. 2b)

- Festuco triflorae-Quercetum rotundifoliae Dahmani 1984 nom. inval. (Art. 1) 
Lit.: Dahmani (1984, 1994), DahmaniMegrerouche (1996a, 1996b, 1997).

Ptilostemono riphaei-Quercetum rotundifoliae Meddour 2010 nom. inval. (Art. 1) Lit.: Meddour (2010).

Pinetalia halepensis Biondi, Blasi, Galdenzi, Pesaresi\&VaggeinBiondi,Allegrezza,Casavecchia, Galdenzi, Gasparri, Pesaresi, Vagge \& Blasi 2014 Thermo-mesomediterranean pine forests of the Central and Eastern Mediterranean

Pistacio lentisci-Pinion halepensis Biondi, Blasi, Galdenzi, Pesaresi \& Vagge in Biondi, Allegrezza, Casavecchia, Galdenzi, Gasparri, Pesaresi, Vagge \& Blasi 2014

Thermo-mesomediterranean pine forests of the Central and Eastern Mediterranean

\section{Genisto quadriflorae-Pinetum halepensis} ass. nova hoc loco

Holotypus (hoc loco): Benabdelli (1996: Tab. 14, rel. 3)

- Calicotomo spinosae-Pinetum halepensis Brakchi 1998 nom. inval. (Art. 1)

- 'Matorral élévé à Pinus halepensis' (Rebbas et al., 2011: 280, Table VI)

Lit.: Benabdelli (1996: Tab. 4, rels. 1, 2, 3 \& 5), Brakchi (1998), Rebbas et al. (2011), Lemouissi (2014).

Arisaro vulgaris-Pinetum halepensis Brakchi 1998 nom. inval. (Art. 1)

Lit.: Brakchi (1998).

Erico arboreae-Pinetum halepensis Brakchi 1998 nom. inval. (Art. 1)

- non Erico arboreae-Pinetum halepensis De Marco \& Caneva 1984

Lit.: Brakchi (1998), Rebbas et al. (2011).

Pistacio lentisci-Rhamnetalia alaterni RivasMartínez 1975

Thermo-mesomediterranean low-grown matorral, macchia and garrigue of the Mediterranean Basin

Syntaxonomic note 1: As Benabid \& Fennane (1994), Benabid (2000) and Fennane (2003) pointed out, the boundaries between the alliances within the Pistacio lentisci-Rhamnetalia alaterni in North Africa are not clear. Already in 1980, Guinochet proposed that "a close examination reveals that the associations described in this have very similar floristic compositions, of- ten differing only in the absence or presence, or even merely dominance, of one or a few, some among fourty species". Clearly, a syntaxonomic revision of the Pistacio lentisci-Rhamnetalia alaterni in North Africa is long overdue.

Syntaxonomic note 2 (L. Mucina): The scrub communities traditionally classified within the Quercetea ilicis have been considered to constitute a in its own right by Julve (1993) who coined the Pistacio lentisci-Rhamnetea alaterni. This deed has not been followed by many (e.g. Theurillat et al., 1995; several issues of the French Prodrome, e.g. de Foucault et al., 2012; it has not been recognised notably in Bardat et al., 2004), but appears to possess some merit especially in the light of the current recognition of scrub classes such as Crataego-Prunetea (separated from Querco-Fagetea), Roso pendulinae-Pinetea mugo vs Vaccinio-Piceetea, Rhododendro hirsutiEricetea carneae vs Erico-Pinetea, Salicetea purpureae vs Alno-Populetea, and Franguletea vs Alnetea glutinosae. Recognition of the importance of vegetation structure (especially complexity of vertical layering and physiognomy) in delimitation of the higher ranks of the BraunBlanquet syntaxonomy is not a new phenomenon (see Westhoff, 1967). I am of the opinion, that the vegetation structure (as an additional criterium) should be consequently pursued also in classification of woodland and scrub vegetation of the Mediterranean.

Asparago albi-Rhamnion oleoidis Rivas Goday ex Rivas-Martínez 1975

Ibero-Maghrebian thermomediterranean sclerophyllous maquis and mantle scrub of semi-arid to subhumid regions

Syntaxonomic note: Maghrebian phytosociologists used the name Oleo-Ceratonion siliquae Braun-Blanquet ex Guinochet \& Drouineau 1944 to accommodate sclerophyllous scrub of the relevant ecological space (semi-arid to subhumid, thermomediterranean, coastal-close habitats). The latter is however, limited (see also Rivas-Martínez et al., 2011) to the northwestern Spanish Valenciano-Catalonian coasts as well as the coast of the Balearic Island, and further to the coastal seaboards of the Ligurian and Tyrrhenian Sea (incl. Corsica, Sardinia, northern coasts of Italy, and the entire western coasts of Apennine Peninsula). The Oleo-Ceratonion is, in south of Spain and further south in North Africa, replaced by the Asparago albi-Rhamnion oleoidis. 


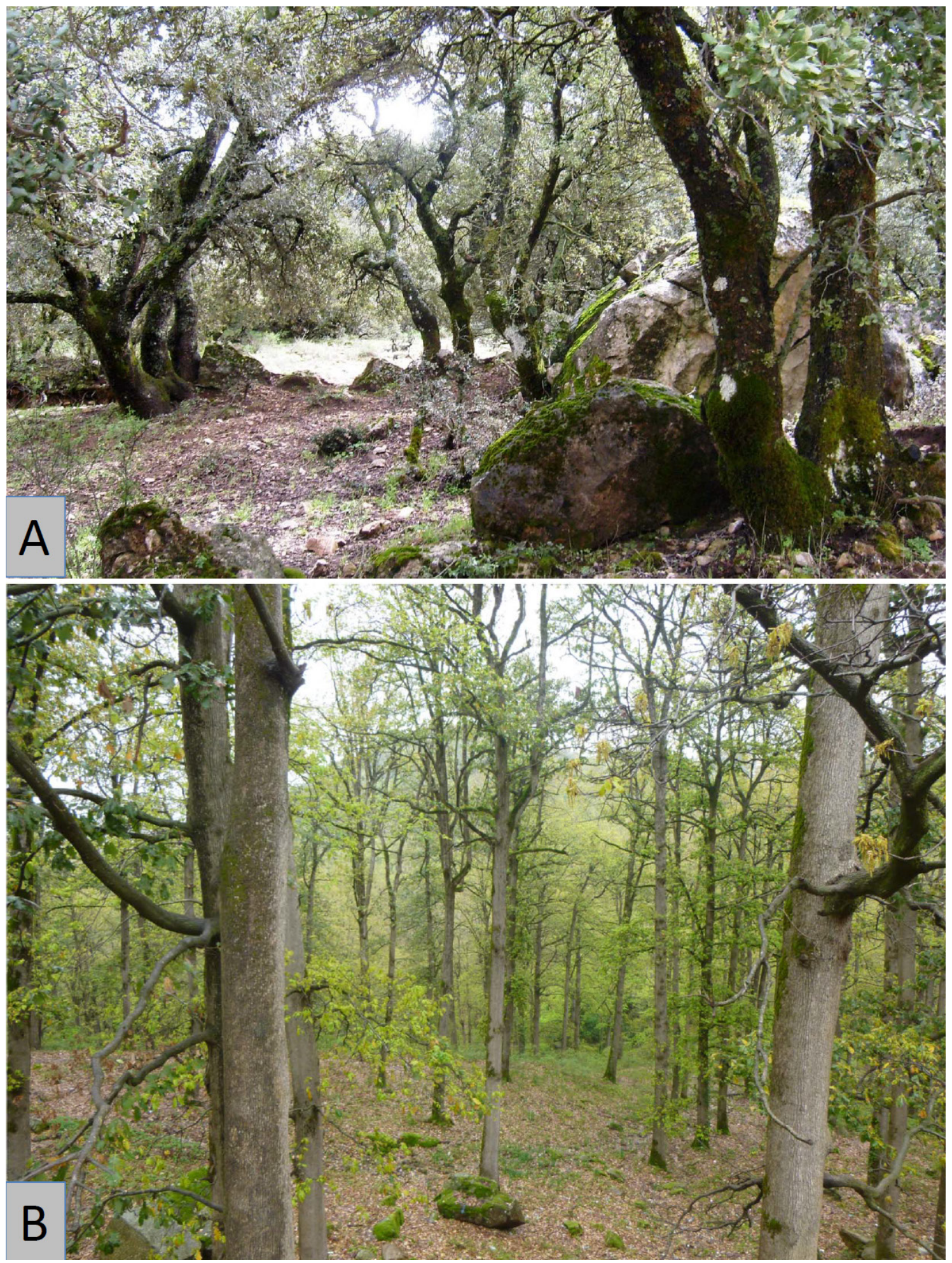

Figure 1. Forest communities of Algeria. A: Balansaeo glaberrimae-Quercetum rotundifoliae, Tizi Tirkabine, Tizi n'Kouilal Pass, Djurdjura Mt; B: Plagio maghrebini-Quercetum canariensis, Yakouren, Béni Ghobri forest. Both photos: R. Meddour. 
- 'Oleo-Ceratonion siliquae' (sensu auct. maghrebianum)

- non Oleo-Ceratonion siliquae BraunBlanquet ex Guinochet \& Drouineau 1944

Smilaco asperae-Pistacietum lentisci (Nègre 1964) nom. nov. hoc loco

- 'Association à Pistacia lentiscus et Olea europaea' Nègre 1964 nom. illeg. (Art. 31)

- Oleo sylvestris-Pistacietum lentisci Nègre 1964 corr. sensu auct. (corr. superfl.)

- 'Groupement à Olea europaea et Pistacia lentiscus'(Toubal, 1986)

- Oleo oleastri-Pistacietum lentisci Sadki 1988 nom. inval. (Art. 1)

- non Oleo sylvestris-Pistacietum lentisci Braun-Blanquet \& Molinier 1951 Lit.: Nègre (1964), De Bélair et al. (1984), Toubal (1986), De Bélair \& Bencheikh-Lehocine (1987), Sadki (1988, 1995), Wojterski (1988, 1990), Khelifi \& Sadki (1995), Toubal \& Toubal (1996b), Meddour (2002).

Phillyreo latifoliae-Pistacietum lentisci Benabid 1982 nom. inval. (Art. 5)

- Phillyreo angustifoliae-Pistacietum lentisci Siab-Farsi, Khelifi \& Kadid 2014 nom. inval. (Art. 5)

- Phillyreo angustifoliae-Pistacietum lentisci Khelifi 2008 nom. inval. (Art. 1) Lit.: Khelifi (2008), Siab-Farsi et al. (2014).

Ephedro fragilis-Pistacietum lentisci Géhu, Kaabèche \& Gharzouli ex Géhu \& Sadki 1996

- Ephedro fragilis-Pistacietum lentisci Géhu \& Sadki 1996 (phantom)

- 'Ephedro fragilis-Lentiscetum' Géhu, Kaabèche \& Gharzouli 1992 nom. inval. (orig. form) (Art. 2b)

- 'Faciès à Ephedra fragilis de l'OleoPistacietum lentisci' (Wojterski, 1988)

- nonEphedrofragilis-Pistacietumlentisci Biondi, Brugiapaglia, Farris, Filigheddu \& Secchi 2004 nom. illeg. (Art. 31)

Nomenclatural note: Géhu \& Sadki (1996, not 1995; see Note on the Ephedro fragilis-Junieretum turbinatae) validated the association by selecting the holotype.
Lit.: Wojterski (1988), Géhu et al. (1992), Géhu \& Sadki (1996), Siab-Farsi et al. (2014).

Bupleuro fruticosi-Euphorbietum dendroidis Géhu, Kaabèche \& Gharzouli 1992 nom. inval. (Art. 5)

- 'Maquis à Euphorbia dendroides'(Géhu et al., 1994a)

- Chamaeropo humilis-Euphorbietum dendroidis Toubal \& Toubal 1996 nom. inval. (Art. 5)

- 'Groupement à Euphorbia dendroides' (Kaabèche et al., 1998)

Lit.: Géhu et al. (1992, 1994a), Toubal \& Toubal (1996a), Kaabèche et al. (1998), Rebbas et al. (2011)

Ampelodesmomauritanicae-Chamaeropetum humilis J. Braun-Blanquet, Font Quer, G. Braun-Blanquet, Frey, Jansen \& Moor 1936

- Pistacio lentisci-Chamaeropetum humilis Brullo \& Marcenò 1985 (syntax. syn.)

- Ampelodesmo mauritanicaeChamaeropetum humilis Quézel, Barbero, Benabid \& Rivas-Martínez 1992 nom. illeg. (Art. 31)

- Chamaeropetum humilis Toubal 1998 (syntax. syn.)

Nomenclatural and syntaxonomic notes: Toubal's (1998), 'Chamaeropetum humilii' was validly described (albeit the name deserves orthographic correction) from Algeria, and it is syntaxonomically identical with the AmpelodesmoChamaeropetum (Braun-Blanquet et al., 1936). The association Pistacio lentisciChamaeropetum humilis Brullo \& Marcenò 1985 (Brullo \& Marcenò, 1985; Brullo et al., 2008) most probably belongs to the same association as well. Géhu \& Sadki (1996: 354-355) have included validly described Chamaeropodo humilis-Artemisietum arborescentis Géhu \& Sadki 1996 into the Oleo-Ceratonion. This classification is not correct since this 'pré-maquis subnitrophile' apparently belongs to the Pegano-Salsoletea. Lit.: Toubal (1998), Mesli (2001), Amara (2014).

Chamaeropo humilis-Asparagetum altissimi Guinochet 1980 nom. inval. (Art. 5) 
Nomenclatural note: Once the name of this association is validated, it would be the prime candidate for nomen inversum since Chamaerops humilis has high cover values that Asparagus altissimus in all 3 relevés in the table in the original publication (Guinochet, 1980: Tab. 7).

Lit.: Guinochet (1980).

Quercetum coccifero-rotundifoliae Hadjadj -Aoul \& Loisel 1999

Lit.: Hadjadj-Aoul \& Loisel (1999), Mesli (2001).

Tetraclini articulatae-Lavanduletum dentatae Dahmani 1984 nom. inval. (Art. 1)

- non Lavandulo dentatae-Tetraclinetum articulatae Fennane 1982 nom. inval. (Art. 1)

- non Lavandulo dentatae-Tetraclinetum articulatae Fennane 1988 nom. inval. (Art. 5)

Lit.: Dahmani (1984), Hadjadj-Aoul (1988).

Calicotomo intermediae-Tetraclinetum articulatae Barbero, Quézel \& RivasMartínez 1981

Lit.: Hadjadj-Aoul (1988), Hadjadj (1991), Hadjadj-Aoul \& Loisel (1999), Medjahdi (2010), Amara (2014).

Ampelodesmo mauritanicae-Tetraclinetum articulatae Hadjadj-Aoul \& Loisel 1999

- 'Groupement à Tetraclinis articulata et Ampelodesma mauritanicum' (Miara, 2011)

- 'G3:Tetraclinisarticulata-Ampelodesma mauritanicum' (Benabdellah, 2011)

Lit.: Hadjadj-Aoul \& Loisel (1999), Benabdellah (2011), Miara (2011), Miara et al. (2012).

Genisto quadriflorae-Tetraclinetum articulatae Hadjadj-Aoul \& Loisel 1999 Lit.: Hadjadj-Aoul \& Loisel (1999).

Comm. 'Groupements à Myrtus communis' (Nègre, 1964)

- 'sous-groupement à Myrtus communis, la myrtaie' (Chevassut, 1956)

Lit.: Chevassut (1956), Nègre (1964), Toubal (1986).

Tetraclini articulatae-Pistacion atlanticae Rivas-Martínez, Costa \& Izco 1986*
Thermo-mesomediterranean sclerophyllous scrub of arid and semi-arid continental regions of the Maghreb

Syntaxonomic note: Fennane (1988) suggested that this was only of very dubious value since it had been originally created to accommodate mainly Tetraclinis associations. Hadjadj-Aoul \& Loisel (1999) as well as Meddour (2010) have cited it for Algeria.

Rosmarino tournefortii-Tetraclinetum articulatae Nègre 1964 nom. invers. et nom. mut. propos.

- 'Callitrieto-Rosmarinetum tournefortii' Nègre 1964 (orig. form)

- Rosmarino tournefortii-Tetraclinetum articulatae Fennane 1987 nom. inval. (Art. 1)

- Rosmarino tournefortii-Tetraclinetum articulatae Fennane 1988 nom. inval. (Art. 5)

Nomenclatural note: In the original name of this association (Nègre, 1964) the suffix -etum should be assigned to the species of higher stratum (Tetraclinis articulata, syn. Callitris quadrivalvis). Therefore we suggest inverting the original name as well as mutating the inverted name since the concept of the genus Callitris has not been in use in North Africa for more than past 20 years. Molecular phylogenetic work (e.g. Gadek et al., 2000; Yang et al., 2012) confirmed that Callitris and Tetraclinis belong to different clades and hence should be considered different at the genus level. Fennane's $(1987,1988)$ Rosmarino tournefortii-Tetraclinetum articulatae is syntaxonomically identical, yet invalidly published. However, validation of this name would create a later homonym.

Lit.: Nègre (1964), Hadjadj-Aoul (1988), Medjahdi (2010). Figure 2C.

Rhuo pentaphyllae-Tetraclinetum articulatae Hadjadj-Aoul 1999

- 'Rhus pentaphyllae-Tetraclinetum articulatae' Hadjadj-Aoul 1988 nom. inval. (Art. 1)

- 'Rhus pentaphyllae-Tetraclinetum articulatae' Hadjadj 1991 nom. inval. (Art. 5)

- 'Groupement à Tetraclinis articulata et Rhus pentaphylla'(Alcaraz, 1991) 
Lit.: Hadjadj-Aoul (1988), Hadjadj (1991), Alcaraz (1991), Hadjadj-Aoul \& Loisel (1999).

Rhamno oleoidis-Tetraclinetum articulatae Hadjadj-Aoul \& Loisel 1999

Lit.: Hadjadj-Aoul \& Loisel (1999).

Junipero turbinatae-Quercetum cocciferae Hadjadj-Aoul \& Loisel 1999

Lit.: Hadjadj-Aoul \& Loisel (1999).

Calicotomo intermediae-Oleetum sylvestris Quézel, Barbero, Benabid, Loisel \& Rivas-Martínez 1988

Lit.: Amara (2014).

Junipero oxycedri-Rhamnion atlanticae Quézel \& Barbero 1986*

Meso-supramediterranean sclerophyllous scrub of subhumid regions of the Maghreb

Juniperoturbinatae-Quercetum rotundifoliae Dahmani-Megrerouche \& Loisel 2003 nom. inval. (Art. 5)

- Junipero turbinatae-Quercetum rotundifoliae Dahmani-Megrerouche 1996 nom. inval. (Art. 2b)

Lit::Dahmani-Megrerouche(1996a,1996b, 1997), Kadi-Hanifi (1998), Dahmani-Megrerouche \& Loisel (2003).

Comm. 'Groupement à Quercus rotundifolia et Juniperus oxycedrus subsp. rufescens' (Miara et al., 2012) Lit.: Miara (2011), Miara et al. (2012)..

Juniperion turbinatae Rivas-Martínez 1975 corr. 1987

Thermomediterranean tall juniper scrub on coastal dune systems of the semi-arid to sub-humid Western Mediterranean seaboards

- Juniperion lyciae Rivas-Mart. 1975 (orig. name)

Ephedro fragilis-Juniperetum macrocarpae Bartolo, Brullo \& Marcenò 1982

- Ephedrofragilis-Juniperetum macrocarpae Géhu \& Géhu-Franck 1986 nom. illeg. (Art. 31)

Nomenclatural and syntaxonomic notes: The Ephedro fragilis-Juniperetum macrocarpae J.M. Géhu \& J. Géhu-Franck 1986 (see Géhu \& Géhu-Franck, 1986; Géhu et al., 1994a), described from Tunisia, is ap- parently syntaxonomically identical with the Ephedro fragilis-Juniperetum macrocarpae Bartolo, Brullo \& Marcenò 1982 (described form Sicily; Brullo et al., 2008) and therefore nomenclaturally should be considered a later homonym.

Lit.: Aimé et al. (1983), Géhu et al. (1992, 1994a), Khelifi et al. (2014).

\section{Ephedro fragilis-Juniperetum turbinatae} Géhu \& Sadki 1996

- Ephedro fragilis-Juniperetum turbinatae (Zaffran 1960) Géhu \& Sadki 1996 (phantom)

Nomenclatural note: The name was effectively not published in 1995, but in March 1996 as indicated clearly on the last page of the Volume XV of Document phytosociologiques N.S. (see Géhu \& Sadki, 1996).

Lit.: Zaffran (1960), Wojterski (1988), Géhu \& Sadki (1996), Siab-Farsi et al. (2014).

Rhamno rotundifoliae-Juniperetum turbinatae Quézel, Barbero, Benabid, Loisel \& Rivas-Martínez 1988

Lit.: Medjahdi (2010).

Clematidi cirrhosae-Juniperetum lyciae Barbero, Quézel \& Rivas-Martínez 1981 nom. inval. (Art. 2b)

Nomenclatural note: The association was described by Barbero et al. (1981: 369370) invalidly since only synoptic table has been presented.

Lit.: Meziani (1984).

Ericion arboreae (Rivas-Martínez ex RivasMartínez, Costa \& Izco 1986) Rivas-Martínez 1987

Mesomediterranean neutrophilous to acidophilous mesic maquis and mantle in the subhumid to humid regions of the Western Mediterranean

Simethibicoloris-Ericetum arboreae Nègre 1964

Lit.: Nègre (1964).

Ericoarboreae-Myrtetum communis Quézel, Barbero, Benabid, Loisel \& Rivas-Martínez 1988

- 'Groupement à Pistacia lentiscus et Erica arborea' (Sadki, 1988)

Lit.: Sadki (1988), Hadjadj (1991), Khelifi \& Sadki (1995), Hadjadj-Aoul \& Loisel (1999), Meddour (2010), Medjahdi (2010). 

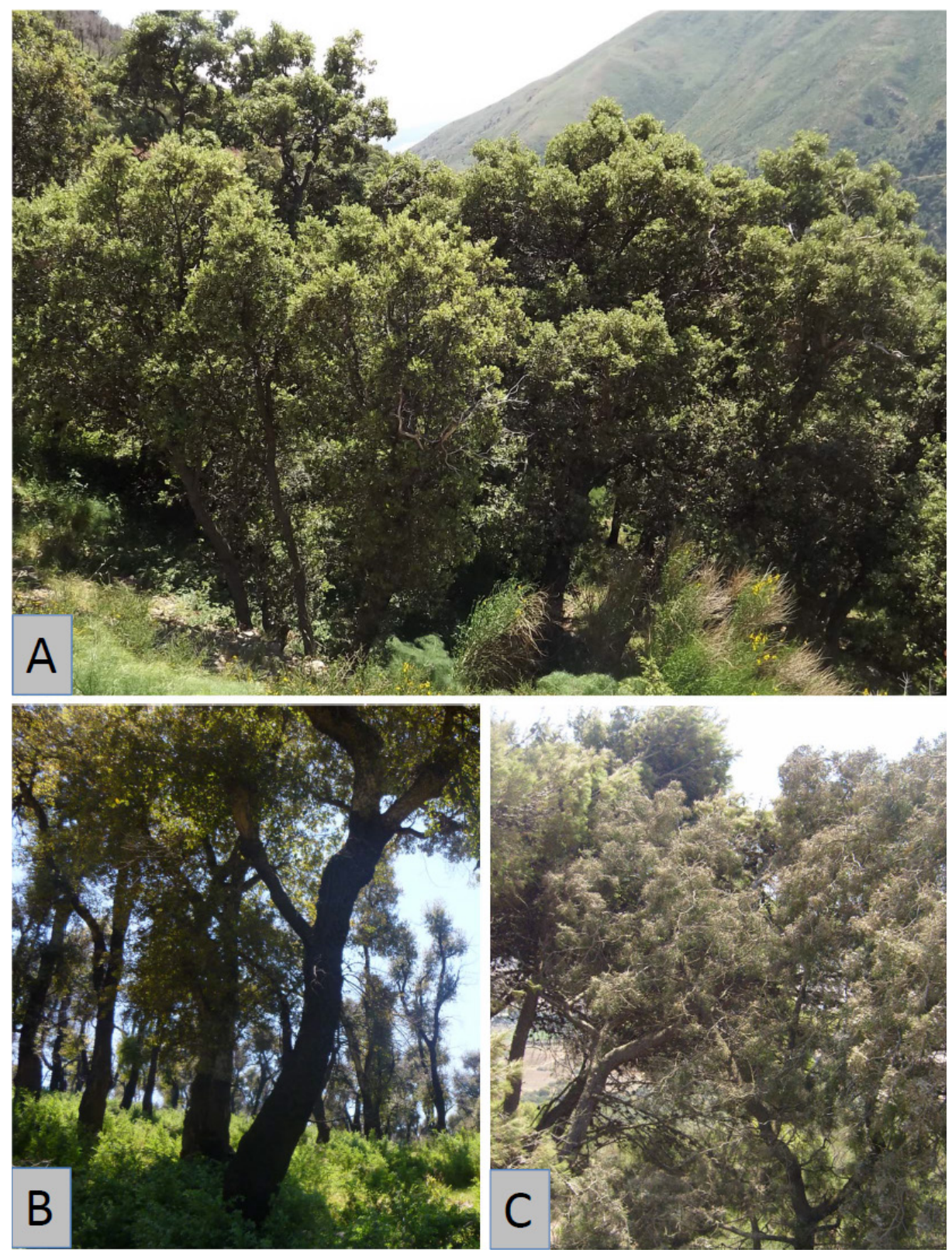

Figure 2. Forest communities of Algeria. A: Phlomido bovei-Quercetum rotundifoliae, Mzarir, southern slope of Djurdjura Mt; B: Cytiso villosi-Quercetum suberis, Mizrana forest, Kabylian coast; C: Rosmarino tournefortii-Tetraclinetum articulatae, Sahel of Tipaza. All photos: R. Meddour.

\section{Erico arboreae-Arbutetum unedonis} Molinier 1937

- 'Erico arboreae-Arbutetum unedo' Mesli 2001 nom. inval. (Art. 1)

Lit.: Mesli (2001).

\section{Erico arboreae-Tetraclinetum articulatae} Hadjadj-Aoul 1988 nom. inval. (Art. 1) Lit.: Hadjadj-Aoul (1988).
Erico arboreae-Quercetum cocciferae Quézel, Barbero, Benabid \& Rivas-Martínez 1992

Lit.: Medjahdi (2010).

Phillyreo latifoliae-Quercetum cocciferae Quézel, Barbero, Benabid, Loisel \& RivasMartínez 1988 
- 'Prasio-Oleetum O. de Bolòs in O. de Bolòs \& Molinier 1969' (phantom; in Guinochet, 1980)

Lit:: Guinochet(1980), Hadjadj-Aoul(1988, 1993), Hadjadj (1991), Meddour (2002).

Genisto ulicinae-Quercetum cocciferae Djaaboub 2008 nom. inval. (Art. 1)

Lit.: Djaaboub (2008).

Periplocion angustifoliae Rivas-Martínez 1975 Infra-thermomediterranean relict low semideciduous sclerophyllous scrub of the coastal arid and semi-arid regions of the southeastern Spain, Sicily and the western North Africa

- Periploco angustifoliae-Tetraclinidion articulatae Rivas-Martínez in Rivas-Martínez et al. 2011 (syntax. syn.)

Syntaxonomic note: This alliance, originally recognised in south-eastern Spain (Rivas-Martínez, 1975; Rivas-Martínez et al., 1986) has not been adopted in Morocco (see Barbero et al., 1981; Benabid \& Fennane, 1994; Benabid, 2000), despite the 'Periploco laevigatae-Tetraclinetum articulatae Benabid 1982' from calcareous substrates of the thermomediterranean belt, does occur in Morocco in the coastal Eastern Rif (Barbero et al., 1982), yet it has not been linked to this unit (Quézel \& Barbero, 1986). In Orania (Western Algeria), this very rare vegetation occurs only in few sites between Oran and Ghazaouet (Medjahdi, 2010), and could possibly also be found as far as Ghomara in Morocco (see Barbero et al., 1981) and around the Alboron Sea (Meddour, 2010).

Periploco angustifoliae-Tetraclinetum articulatae Benabid ex Rivas-Martínez et al. 2011

- Periploco laevigatae-Tetraclinetum articulatae Benabid 1982 nom. inval. (Art. 1)

- Periploco laevigatae-Tetraclinetum articulatae Benabid 1985 nom. inval. (Art. 5)

Nomenclatural note: This association has been selected by Rivas-Martínez et al. (2011) as the holotype of the Periploco angustifoliae-Tetraclinidion articulatae.

Lit.: Medjahdi (2010).

Euphorbio bivonae-Rhoetum tripartitae Siab-Farsi, Khelifi \& Kadid 2014 nom. inval. (Art. 5)
- 'Euphorbio bivonae-Rhusetum tripartitae' Khelifi 2008 nom. inval. (Art. 1)

Lit.: Khelifi (2008), Siab-Farsi et al. (2014).

Comm. 'Brousse à Periploca laevigata et Ziziphus lotus' (Géhu et al., 1994a)

Lit.: Géhu et al. (1994a).

Genisto tricuspidatae-Calicotomion spinosi Dahmani-Megrerouche \& Loisel all. nova hoc loco*

Thermo- and mesomediterranean low maquis on acidic or decarbonated soils in subhumid and humid regions of Central Algeria

Holotypus (hoc loco): Calicotomo spinosaeQuercetum rotundifoliae Dahmani-Megrerouche \& Loisel ex Meddour, Meddour-Sahar, Zeraia \& Mucina 2017 (see below).

Diagnostic taxa: Ampelodesmos mauritanicus, Calicotome spinosa, Cistus creticus subsp. creticus, Genista tricuspidata

- Genisto tricuspidatae-Calicotomion spinosi Dahmani 1984 nom. inval. (Art. 1)

- Genisto tricuspidatae-Calicotomion spinosi Dahmani-Megrerouche \& Loisel 2003 nom. inval. (Arts. 5 \& 8)

Syntaxonomic note: This vegetation of central Algerian distribution includes matorrals and coppice of green oak, whose extension is alarming due to the frequency of fires. The degradation of green oak or cork oak forest, at thermomediterranean and mesomediterranean belts, in subhumid or even humid bioclimate, resulted in plant communities dominated physiognomically by Calicotome spinosa, Ampelodesmos mauritanica, Genista tricuspidata subsp. tricuspidata, which are characteristic species (Dahmani, 1997). These are not typical tall-scrub formations, but as was mentioned by Quézel et al. (1988; see also Meddour, 2010) about some Moroccan vegetation: "complex and heterogeneous vegetation structures, mainly integrating heavily anthropized degradation stages ('dematorralisation' process), in which the chamaephytes linked to the Cisto-Lavanduletea or Rosmarinetea can play an important physiognomic role and whose interpretation is not easy".

Calicotomo spinosae-Quercetum rotundifoliae Dahmani-Megrerouche \& Loisel ass. nova hoc loco

Holotypus (hoc loco): Dahmani-Megrerouche \& Loisel (2003: Table 6, rel. 3) 
- Calicotomo spinosae-Quercetum rotundifoliae Dahmani-Megrerouche 1996 nom. inval. (Art. 2b)

- Calicotomo spinosae-Quercetum rotundifoliae Dahmani-Megrerouche \& Loisel 2003 nom. inval. (Art. 5)

- 'Groupement à Quercus rotundifolia et Genista tricuspidata' (Miara, 2011)

Lit.: Dahmani-Megrerouche (1996a, 1996b, 1997), Mesli (2001), Dahmani-Megrerouche \& Loisel (2003), Boulaacheb (2009), Meddour (2010), Miara (2011), Miara et al. (2012), Lemouissi (2014).

Cisto salviifolii-Quercetum rotundifoliae Dahmani-Megrerouche \& Loisel ass.nova hoc loco

Holotypus (hoc loco): Dahmani-Megrerouche \& Loisel (2003: Table 8, rel. 8)

- Cisto salviifolii-Quercetum rotundifoliae Dahmani-Megrerouche 1996 nom. inval. (Art. 2b)

- Cisto salviifolii-Quercetum rotundifoliae Dahmani-Megrerouche \& Loisel 2003 nom. inval. (Art. 5)

Lit.: Dahmani-Megrerouche (1996a, 1996b, 1997), Brakchi (1998), Dahmani-Megrerouche \& Loisel (2003), Meddour et al. (2010), Miara et al. (2012).

Arbuto unedoni-Quercetum rotundifoliae Miara, Hadjadj-Aoul \& Ait Hammou 2012

- 'Groupement à Quercus rotundifolia et Arbutus unedo' (Miara, 2011)

Lit.: Miara (2011), Miara et al. (2012).

Pistacio lentisci-Calicotometum spinosae Boussouf 2004 nom. inval. (Art. 1)

Lit.: Boussouf (2004).

Calicotomo intermediae-Quercion cocciferae Dahmani-Megrerouche \& Loisel all. nova hoc loco*

Thermo- and mesomediterranean scrub on calcareous soils in semi-arid or subhumid regions of Western Algeria

Holotypus (hoc loco): Calicotomo intermediae-Quercetum rotundifoliae Dahmani-Megrerouche \& Loisel ex Meddour, Meddour-Sahar, Zeraia \& Mucina 2017 (see below)

Diagnostic taxa: Calicotome infesta subsp. intermedia, Quercus coccifera, Quercus ilex subsp. ballota, Chamaerops humilis
- Calicotomointermediae-Quercioncocciferae Dahmani 1984 nom. inval. (Art. 1)

- Calicotomointermediae-Quercioncocciferae Dahmani-Megrerouche \& Loisel 2003 nom. inval. (Arts. 5 \& 8)

Calicotomo intermediae-Quercetum rotundifoliae Dahmani-Megrerouche \& Loisel ass. nova hoc loco

Holotypus (hoc loco): Dahmani-Megrerouche \& Loisel (2003: Table 9, rel. 4)

- Calicotomointermediae-Quercetum rotundifoliae Dahmani-Megrerouche 1996 nom. inval. (Art. 2b)

- Calicotomo intermediae-Quercetum rotundifoliae Dahmani-Megrerouche \& Loisel 2003 nom. inval. (Art. 5)

Lit.: Dahmani-Megrerouche (1996a, 1996b, 1997), Kadi-Hanifi (1998), DahmaniMegrerouche \& Loisel (2003).

Ampelodesmo mauritanicae-Quercetum cocciferae Kadik 2005 nom. inval. (Art. 1) Lit.: Kadik (2005).

Loto dorycnium-Quercion rotundifoliae Djebaili all. nova hoc loco*

Tall-scrub 'pre-forest' green-oak and pine vegetation of the Saharan Atlas

Holotypus (hoc loco): Loto dorycniumPinetum halepensis Djebaïli in Meddour, Meddour-Sahar, Zeraia \& Mucina 2017 (see below)

Nomenclature note: The concept of this was originally conceived by Prof. Djebaïli (19351994), a grand personality of Algerian biology who tragically deceased. (https://fr.wikipedia. org/wiki/Salah Djebaïli). As a token of our appreciation, we suggest that this alliance should be described under his name.

Diagnostic species: Asparagus acutifolius, Ephedra altissima, Lotus dorycnium (syn. Dorycnium suffruticosum, D. pentaphyllum), Phillyrea media, Pinus halepensis, Pistacia terebinthus, Quercus ilex subsp. ballota

- 'Alliance à Pinus halepensis et Quercus ilex' Djebaïli 1978 nom. inval. (Art. 1)

- 'Alliance à Pinus halepensis et Quercus ilex' Djebaïli 1984 nom. inval. (Art. 8)

- 'Alliance à Pinus halepensis et Quercus ilex' Djebaïli 1990 nom. inval. (Art. 8)

- 'Pino halepensis-Quercion rotundifoliae Djebaïli 1978' corr. Meddour 2010 nom. inval. (Art. 1; invalid nomen corrigendum) 
Syntaxonomic note: Kaabèche (1995) has shown, by using numerical analyses, that the 'Pinus halepensis plant community' of the SaharanAtlas (Kadik, 1983), the 'Pinus halepensis and Quercus ilex community' and the 'Pinus halepensis and Juniperus phoenicea community' of Ksour Mountains (both by Bouzenoune, 1984), and the 'forest plant communities' of the Ouled Naiil Mountains (Kaabèche, 1990), have close floristic affinities with vegetation described by Djebaili (1978). Undoubtedly, they should belong to the PistacioRhamnetalia. Yet, the syntaxonomic classification of these units (one association with several subassociations or a new alliance with several associations), remained unclear. Although Kaabèche (1995) accepted the idea of vegetation 'with Pinus halepensis and Quercus ilex', the concept remained poorly defined due to the choice of characteristics and differentials species of matorrals. It appears, however, that coining of a new name (alliance) to accommodate the 'pre-forest' (scrub) green-oak and pine formations of the Saharan Atlas is justified and supported by the notion of 'continental facies of the Saharan Atlas' for the pine-dominated vegetation as described by Maire (1926). Other characteristic species are Genista pseudopilosa, Pistacia lentiscus, Thymelaea nitida, etc. The same name was previously proposed by Celles (1975, in Kaabèche, 1995) for the Saharan Atlas as well.

Loto dorycnium-Pinetum halepensis Djebailli ass. nova hoc loco

Neotypus (hoc loco): Djebaïli (1984: Table 1, rel. 195)

Syntaxonomic note: This association (where Argyrolobium linneanum is significatively present) appears to have close floristic affinities with the Argyrolobio linneani-Pinetum halepensis Achhal 1986 (see Quézel \& Barbero, 1986; Fennane, 2003) described from the Central High Atlas, but belonging to the Tetraclini-Pistacion atlanticae.

- Dorycnio suffruticosi-Phillyreetum mediae Djebaïli 1978 nom. inval. (Art. 1)

- Dorycnio suffruticosi-Phillyreetum mediae Djebaïli 1990 nom. inval. (Art. 2b)

Lit.: Djebaïli (1978, 1984, 1990), Meddour (2010), Chermat (2014).

Coronillo valentinae-Quercetum Guinochet ex Meddour ass. nova hoc loco
Holotypus (hoc loco): Guinochet (1980: Table 8, rel. 1)

- 'Querco-Coronilletum valentinae'Guinochet 1980 nom. inval. (Art. 5)

- Coronillo valentinae-Quercetum rotundifoliae Guinochet 1980 nom. inval. (Meddour 2002; Art. 2b)

Lit.: Guinochet (1980), Meddour (1994a, 2002).

Cytisetea scopario-striati Rivas-Martínez 1974 Mediterranean and (sub)atlantic temperate broomy scrub (retamal, piornal, escobonal) seral to forests on acidic substrates

Cytisetalia scopario-striati Rivas-Martínez 1974 Western and Central Mediterranean thermoto supramediterranean and submediterranean broomy cytisoid scrub

- Retametalia sphaerocarpae Rivas Goday 1980 (syntax.syn.)

Retamion monospermae Rivas-Martínez \& Cantò in Rivas-Martínez, Fernández-González, Loidi, Lousã \& Penas 2002 Lusitano-Andalusian and Tingitanian seral broomy scrub on deep littoral soils and palaeodune regosols.

Ononido variegatae-Retametum monospermae Pignatti 1952

Lit.: Géhu et al. (1998).

Retametum monospermae (Thomas 1969) Géhu, Kaabèche et Gharzouli 1992 - 'GroupementàRetamabovei'(Thomas, 1969)

- Retametum monospermae Thomas 1968 (phantom; see Géhu et al. 1992)

- Retametum bovei Thomas 1968 (phantom; see Géhu et al., 1994a)

- Pycnocomo rutifoliae-Retametum bovei Khelifi, Siab-Farsi \& Kadid 2014 nom. illeg. (Art. 31)

- Pycnocomono rutifolii-Retametum monospermae Pérez Chiscano 1982 nom. inval. (Art. 5)

Nomenclatural note: This community was, for the first time, described by Thomas (1969) as 'groupement à Retama bovei'. Géhu et al. (1992, see also 1994a) later suggested two association names (Retametum monospermae and Retametum bovei, resp.), and attributed erroneously to Thomas (1968). Creation 
of a nomen novum for the 'groupement à Retama bovei' by Géhu et al. (1992) is a possibility and therefore we suggest that the correct name should read 'Retametum monospermae (Thomas 1969) Géhu et al. 1992'. Although Géhu et al. (1992) have not explicitly assigned the nomenclatural type, only one element (relevé) is available for typification in their paper, hence this relevé becomes automatically the holotype.

- non Centaureo sphaerocephalaeRetametum monospermae Tregubov 1963 Lit.: Thomas (1969), Géhu et al. (1992, 1994a), Khelifi (2008), Khelifi et al. (2014).

\section{SUBMEDITERRANEAN WOODLANDS AND SCRUB}

Junipero-Pinetea sylvestris Rivas-Martínez 1965 nom. invers. propos.

Relict oromediterranean and submediterranean orotemperate dry pine forests, juniper woods and related scrub of the Mediterranean - Ephedro majoris-Juniperetea phoeniceae Quézel \& Barbero 1981 nom. inval. (Art. 8)

Nomenclatural note: A list of character species is given for the Ephedro-Juniperetea by Quézel \& Barbero (1981: 1141), however the holotype was not designated (two invalidly published orders were described in the same paper; see below).

\section{Ephedro majoris-Juniperetalia phoeniceae} Quézel \& Barbero ex Mucina \& Meddour ordo nov. hoc loco*

Maghrebian montane-mediterranean and lower oromediterranean juniper scrub and woodlands in semi-arid and arid regions Holotypus (hoc loco): Ephedro nebrodensis-Juniperion phoeniceae Quézel \& Barbero in Asensi, Díez-Garretas \& Quézel 2007 (Asensi et al., 2007: Phytocoenologia 37: 599-623).

- Thymo hirti-Juniperetalia phoeniceae El Hamrouni 1978 nom. inval. (Art. 8)

- Ephedro majoris-Juniperetalia phoeniceae Quézel \& Barbero 1981 nom. inval. (Art. 8)

Nomenclatural note: A list of character species is given by Quézel \& Barbero (1981: 1141), however no aliance was described in this paper, hence the names remains invalid.

- Ephedro majoris-Juniperetalia phoeniceae Quézel \& Barbero (1981) 1986 nom. inval. (Art. 8)
Nomenclatural note: Since the Ephedro majoris -Juniperetea phoeniceae Quézel \& Barbero 1981 has been invalidly described at time when Quézel \& Barbero (1986: 106) attempted down-ranking of this to the level, the name 'Ephedro majorisJuniperetalia phoeniceae Quézel \& Barbero (1981) 1986' remains invalid.

- Ephedro-Juniperetalia Quézel \& Barbero ex Quézel, Barbero, Benabid, Loisel \& RivasMartínez 1988 nom. inval. (Art. 5)

Nomenclatural note: This name was supposedly validated by Quézel et al. (1988: 100), however since these authors chosen the Junipero thuriferae-Quercion rotundifoliae Quézel \& Barbero 1980' as the type (holotypus), the name remains invalidlypublished(contrary to whatAsensi et al., 2007 would claim). There is no publication by Quézel \& Barbero (1980) cited in Quézel et al. (1988) that would contain validly described of this name. Therefore, the name Ephedro-Juniperetalia remains invalidly published.

Ephedro nebrodensis-Juniperion phoeniceae Quézel \& Barbero in Asensi, Díez-Garretas \& Quézel 2007*

Thermo- and mesomediterranean juniper scrub of arid and semi-arid regions of the Maghreb, forming mantle of the Tetraclini-Pistacion

Nomenclatural note: Asensi et al. (2007: 607) selected the Coronillo ramosissimaeJuniperetum turbinatae Quézel \& Barbero in Asensi, Díez-Garretas \& Quézel 2007 as the holotype of the Ephedro nebrodensisJuniperion phoeniceae. This association was validly described by Asensi et al. (2007: 608). These authors have used Ephedra nebrodensis Tineo as one of the eponymous species. Ephedra nebrodensis Tineo is considered a synonym of $E$. major subsp. villarsii; see www.emplantbase.org). Keeping the epitheton 'majoris' would have been more appropriate.

- Ephedro majoris-Juniperion phoeniceae Quézel \& Barbero (1981) 1986 nom. inval. (Art. 8)

Nomenclatural note: Since the Ephedro majoris-Juniperetalia phoeniceae Quézel \& Barbero 1981 has been invalidly described at time when Quézel \& Barbero (1986) attempted the down-ranking of this to the level, the name 'Ephedro majorisJuniperion phoeniceae Quézel \& Barbero (1981) 1986' remains invalid. 
- Ephedro majoris-Juniperion phoeniceae Quézel \& Barbero in Quézel \& Médail 2003 nom. inval. (Art. 8)

Comm. 'Groupement à Fraxinus xanthoxylloides et Juniperus phoenicea' (Abdessemed, 1981)

Taxonomic note: Fraxinus xanthoxylloides (G. Don) Wall. ex A. DC. was erroneously identified; the correct name is Fraxinus dimorpha Coss. \& Durieu - an AlgerianMoroccan endemic species.

Lit.: Abdessemed (1981).

Junipero thuriferae-Quercion rotundifoliae Quézel \& Barbero ex Quézel, Barbero, Benabid, Loisel \& Rivas-Martínez 1988*

Montane-mediterranean and supramediterranean mixed juniper-oak woodlands in semi-arid, cold, subhumid temperate regions of the Maghreb, forming mantle of the Querco-Cedretalia atlanticae

Nomenclatural note: Quézel et al. (1988: Ecol. Medit. 14 (1/2): 77-122) have chosen the Buxo balearicae-Quercetum rotundifoliae Barbero, Quézel \& RivasMartínez 1981 as the holotype of the Junipero thuriferae-Quercion rotundifoliae, and hence correctly validated the name.

- Junipero thuriferae-Quercion rotundifoliae Quézel \& Barbero (1981) 1986 nom. inval. (Art. 8)

Nomenclatural note: Since the Ephedro majoris-Juniperetalia phoeniceae Quézel \& Barbero 1981 has been invalidly described at time when Quézel \& Barbero (1986) attempted downranking of this to the level, the name 'Ephedro majorisJuniperion phoeniceae Quézel \& Barbero (1981) 1986' remains invalid.

- Junipero africanae-Quercion rotundifoliae Quézel \& Barbero ex Quézel, Barbero, Benabid, Loisel \& Rivas-Martínez 1988 corr. Barbero, Lebreton \& Quézel 1994 (phantom) Nomenclatural note: This is a phantom name since there was no formal correction performed by Barbero et al. (1994). Merely, on page 31, these authors cited 'Junipero thuriferae (africanae)-Quercionrotundifoliae'-obviously referring to the fact that the African subspecies of $J$. thurifera is called $J$. thurifera subsp. africana.

- 'Junipero thuriferae (africanae)-Quercion rotundifoliae Quézel \& Barbero 1986' (corr. superfl.)
Nomenclatural note: This name (used by Barbero et al., 1994; see above) is a result of superfluous addition of subspecific epitheton and hence it is illegitimate, equally as is illegitimate the name of this in Quézel \& Barbero (1986).

\section{Juniperothuriferae-Quercetum rotundifoliae Quézel \& Barbero 1981}

- 'Groupement à Juniperus thurifera' (Abdessemed, 1981)

- non Junipero thuriferae-Quercetum rotundifoliae Rivas-Martínez 1982 nom. inval. (Art. 2b)

- non Junipero thuriferae-Quercetum rotundifoliae Rivas-Martínez 1987 nom. illeg. (Art. 31)

Syntaxonomic note: According to Dahmani (1994), 'groupement à Juniperus thurifera' (Abdessemed, 1981) is similar to the Junipero thuriferae-Quercetum rotundifoliae Quézel \& Barbero 1981, described in Morocco. We share this opinion.

Lit.: Abdessemed (1981), Dahmani (1994).

Comm. 'Groupement à Fraxinus xanthoxylloides et Quercus rotundifolia' (Abdessemed, 1981)

- 'Groupement à Quercus ilex et Fraxinus dimorpha' (Beghami, 2013)

Lit.: Abdessemed (1981), Beghami (2013).

Lonicero kabylicae-Juniperion hemisphaericae Quézel \& Barbero 1989*

Montane-mediterranean to oromediterranean (spanning elevations 1500 and $2200 \mathrm{~m}$ ) low juniper scrub on limestone and dolomite, in cold and perhumid Djurdjura and Babors Mts (Tellian Atlas)

Cynosuro balansae-Juniperetum hemisphaericae Quézel \& Barbero 1989

- 'Groupement à Juniperus communis var. hemisphaerica' (Wojterski, 1988)

Lit.: Wojterski (1988), Quézel \& Barbero (1989), Meddour (2001, 2010), Meddour et al. (2010).

Daphno oleoidis-Juniperetum sabinae Quézel \& Barbero 1989

Lit.: Quézel \& Barbero (1989), Meddour et al. (2010).

Buxo sempervirentis-Cerastietum gibraltarici Gharzouli 1989 nom. inval. (Art. 1) 
Lit.: Gharzouli (1989), Meddour \& Géhu (1998).

Quercetea pubescentis Doing-Kraft ex Scamoni \& Passarge 1959

Oak, mixed deciduous and conifer open forests in warmer habitats in the cool-temperate nemoral zone of Central and Southern Europe and in the supramediterranean belt of the Mediterranean, Asia Minor and Middle East

Querco-Cedretalia atlanticae Barbero, Quézel \& Rivas-Martínez ex Quézel \& Barbero 1989*

Oak forests of the warm-temperate regions in the nemoral zone of Central and Southern Europe and relic supramediterranean firpine and oak forests of the Mediterranean Holotypus: Paeonio atlanticae-Cedrion atlanticae Barbero, Quézel \& Rivas-Martínez ex Quézel \& Barbero 1989 (assigned by Quézel \& Barbero, 1989: 99)

Syntaxonomic note: This Maghrebian unites at present almost all forest formations of deciduous oaks (Quercus faginea, $Q$. canariensis, Q. pyrenaica, Q. afares, etc.), Atlas cedar (Cedrus atlantica) and endemic Maghrebian firs (Abies maroccana, Abies numidica) occurring in humid and perhumid (or even subhumid) and cold bioclimates typical of the supramediterranean and montane-mediterranean belts (Barbero et al., 1974, 1981; Barbero \& Quézel, 1975; Benabid, 1982, 1984). Soils, at least in dense, well-preserved stands, are deep, brown forest soils (Barbero \& Quézel, 1975). In Algeria, one of the main centers of distribution of this order, the communities of this are found in the highest Tellian Massifs and the AurèsBélezma Mts (Géhu et al., 1998; Meddour \& Géhu, 1998).

- Querco-Cedretalia atlanticae Barbero, Loisel \& Quézel 1974 nom. inval. (Art. 8)

Nomenclatural note: The description of this in Barbero et al. (1974) is not sufficient since, besides the listed of diagnostic species, no has been clearly classified within the Querco-Cedretalia atlanticae. Although Barbero \& Quézel (1975) did assign one association (association à Abies numidica et Asperula odorata Quézel 1956) in this order, the name of the remained invalidly published. The validation was done later by Quézel \& Barbero (1989).
Paeonio atlanticae-Cedrion atlanticae Barbero, Quézel \& Rivas-Martínez ex Quézel \& Barbero 1989*

This includes majority of the hilltop forest plant communities (zeen oak, cedar and Abies numidica stands) in the Kabylian sector (Djurdjura, Akfadou and Babors), and in the Tellian Atlas of Algeria

- Paeonio atlanticae-Cedrion atlanticae Barbero, Quézel \& Rivas-Martínez 1981 nom. inval. (Art. 5)

Senecioni perralderiani-Cedretum atlanticae Quézel \& Barbero 1989

Lit.: Quézel \& Barbero (1989), Yahi (1995, 2007), Gharzouli (2007), Meddour et al. (2010). Figure 3B.

Bunio alpini-Cedretum atlanticae Meddour 1994

- Bunio atlantici-Cedretum atlanticae Meddour 1994 nom. mut. propos.

Lit.: Meddour (1994a, 1994b, 2002), Yahi et al. (1999), Yahi (2007). Figure 3C.

Balansaeo glaberrimae-Cedretum atlanticae Barbero, Quézel \& RivasMartínez 1981

- Conopodio glaberrimi-Cedretum atlanticae Barbero, Quézel \& RivasMartínez 1981 corr. Meddour 2010 (corr. illeg.)

Syntaxonomic note: In the protologue, this association is classified into the BalansaeoQuercion. However, the relevé table of this association, suggests that the mesic elements (of the Quercetea pubescentis, incl. Querco-Cedretalia) are more prominent that those of the Quercetea ilicis. Lit.: Dahmani-Megrerouche (1996a, 1996b, 1997).

\section{Cerastio atlantici-Cedretum atlanticae} Yahi in Yahi, Médiouni \& Géhu 1999 nom. inval. (Art. 2b)

- Cerastio atlantici-Cedretum atlanticae Yahi 1995 nom. inval. (Art. 1)

Lit.: Yahi (1995), Yahi et al. (1999), Yahi \& Mediouni (2000), Yahi (2007).

Senecioni gallerandiani-Cedretum atlanticae Yahi in Yahi, Médiouni \& Géhu 1999 nom. inval. (Art. 2b) 
- Senecioni gallerandiani-Cedretum atlanticae Yahi 1995 nom. inval. (Art. 1)

Lit.: Yahi (1995), Yahi et al. (1999), Yahi \& Mediouni (2000).

Biscutello raphanifoliae-Cedretum atlanticae Yahi, Médiouni \& Géhu 1999 nom. inval. (Art. 2b)

- Biscutello raphanifoliae-Stachyetum algeriensis Gharzouli 1989 nom. inval. (Art. 1)

Lit.: Gharzouli (1989), Yahi et al. (1999).

Saturejobaborensis-Cedretum atlanticae Gharzouli 2007 nom. inval. (Art. 1)

In the header of the relevé table in Gharzouli (1997), this name was used. Lit.: Gharzouli (2007).

Sorbo ariae-Cedretum atlanticae Gharzouli 2007 nom. inval. (Art. 1) Lit.: Gharzouli (2007).

Cedro atlanticae-Aceretum monspessulani Azira-Atroune 2001 nom. inval. (Art. 1)

Lit.: Azira-Atroune (2001).

Sileno atlanticae-Cedretum atlanticae Meddour 2010 nom. inval. (Art. 1) Lit.: Meddour (2010).

Physospermo verticillati-Cedretum atlanticae Meddour 2010 nom. inval. (Art. 1)

Lit.: Meddour (2010).

Potentillo micranthae-Cedretum atlanticae Meddour 2010 nom. inval. (Art. 1)

Lit.: Meddour (2010). Figure 3A.

Junipero hemisphaericae-Cedretum atlanticae Meddour 2010 nom. inval. (Art. 1)

Lit.: Meddour (2010).

\section{Lamio garganici-Cedrion atlanticae}

Abdessemed all. nova hoc loco*

Cedar forests of the Saharan Atlas (Aurès, Belezma and Hodna Mts) in subhumid (locally semi-arid) and pronounced continental bioclimate
Holotypus (hocloco): RanunculoaurasiaciCedretum atlanticae Meddour, MeddourSahar, Zeraia \& Mucina 2017 (see below) Diagnostic taxa: Carum montanum, Cedrus altantica, Cephalanthera longifolia, Lamium garganicum subsp. garganicum, Ranunculus aurasiacus

- Lamio numidici-Cedrion atlanticae Abdessemed in Wojterski 1988 nom. inval. (Art. 8)

- Lamio numidici-Cedrion atlanticae Abdessemed in Dahmani-Megrerouche 1996 nom. inval. (Art. 8)

- Lamio numidici-Cedrion atlanticae Abdessemed 1981 nom. inval. (Art. 1)

- Lamio numidici-Cedrion atlanticae Abdessemed 1984 nom. inval. (Art. 8)

- Lamio numidici-Cedrion atlanticae Abdessemed in Yahi, Médiouni \& Géhu 1999 nom. inval. (Art. 8)

- non Violo munbyanae-Cedrion atlantici Barbero, Quézel \& Rivas-Martínez 1981 nom. inval. (Art. 5)

- non Violo munbyanae-Cedrion atlantici Barbero, Quézel \& Rivas-Martínez ex Quézel \& Barbero 1989

Ranunculo aurasiaci-Cedretum atlanticae ass. nova hoc loco

Holotypus (hoc loco): Abdessemed in Wojterski (1988: Tab. 52, rel. 1)

- Violo munbyanae-Juniperetum communis Abdessemed 1981 nom. inval. (Art. 1)

-Violomunbyanae-Juniperetumhemisphaericae Abdessemed 1981 corr. auct., nom. inval. (Art. 1; invalid nom. corr.)

Nomenclatural note: Correction of this name (replacement of 'communis' by 'hemipshaericae') is not admissible because there are two taxa listed in the original diagnosis (in unpublished thesis of Abdessemed, 1981), namely $J$. communis var. hemipshaerica and $J$. communis subsp. eu-communis and the author used explicitly 'communis' as the eponymous species. If effectively published, the name Violo munbyanae-Juniperetum communis cannot be used since none of the eponymous species is a species of the dominant layer. This is a forest community, dominated by Cedrus altlantica.

- Violo munbyanae-Cedretum atlanticae (Abdessemed 1981) Meddour \& Géhu 1998 nom. inval. (Art. 1; invalid nom. nov.)

Lit.: Abdessemed (1981), Abdessemed in Wojterski (1988), Meddour \& Géhu (1998). 

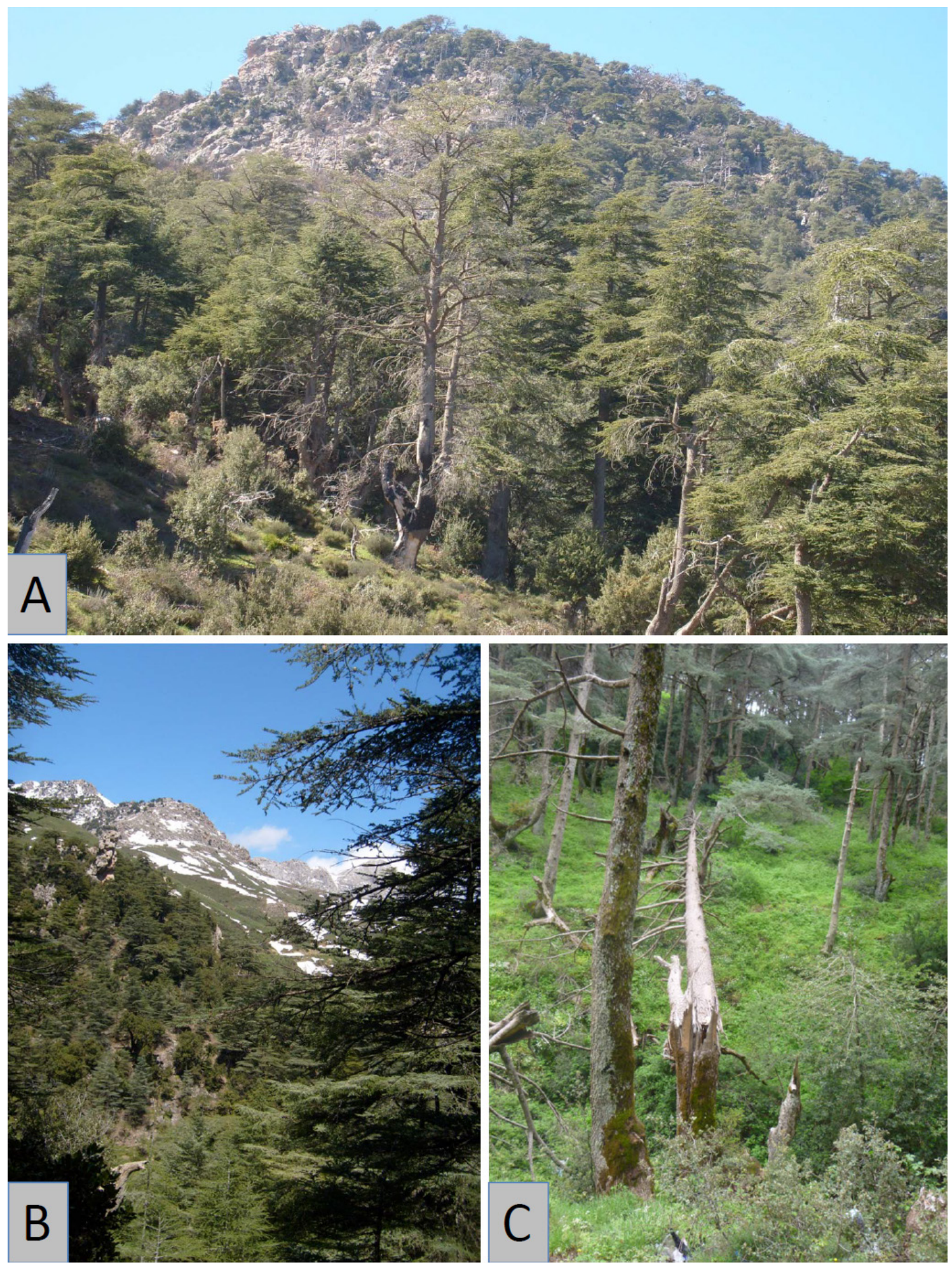

Figure 3. Forest communities of Algeria. A: Potentillo micranthae-Cedretum atlanticae, Djebel Taouialt, Djurdjura Mt; B: Senecioni perralderiani-Cedretum atlanticae, Tigounatine forest, Djurdjura; C: Bunio atlantici-Cedretum atlanticae, Chréa, Tellian Atlas. All photos: R. Meddour. 
Berberido hispanicae-Cedretum atlanticae Benabid 1994 nom. inval. (Art. 2b)

- Cedro atlanticae-Berberidetum hispanicae Abdessemed 1981 nom. inval. (Art. 1).

- Berberido hispanicae-Cedretum atlanticae Benabid 1992 nom. inval. (Art. 1)

Lit.: Abdessemed (1981).

Ranunculo spicati-Cedretum atlanticae Abdessemed in Dahmani-Megrerouche 1996 nom. inval. (Art. 2b)

- Cedro atlanticae-Ranunculetum spicati Abdessemed 1981 nom. inval. (Art. 1)

Lit.: Abdessemed (1981, 1984), DahmaniMegrerouche (1996a, 1996b, 1997).

Cedro atlanticae-Quercetum rotundifoliae Abdessemed 1984 nom. inval. (Art. 2b)

- Cedro atlanticae-Quercetum rotundifoliae Abdessemed 1981 nom. inval. (Art. 1)

Lit.: Abdessemed (1981, 1984), DahmaniMegrerouche (1996a, 1996b, 1997).

Aceri monspessulani-Smyrnietum olusatri Abdessemed 1981 nom. inval. (Art. 1)

- Acero monspessulani-Cedretum atlanticae (Abdessemed 1981) Meddour \& Géhu 1998 nom. inval. (Art. 1; invalid nom. nov.)

Nomenclatural note: If effectively published, the name should read: Smyrnio olusatriCedretum atlanticae.

Lit.: Abdessemed (1981), Meddour \& Géhu (1998).

Lonicero etruscae-Ilicetum aquifolii Abdessemed 1981 nom. inval. (Art. 1)

- Ilici aquifolii-Cedretum atlanticae (Abdessemed 1981) Meddour \& Géhu 1998 nom. inval. (Art. 1; invalid nom. nov.)

- 'Association à Ilex aquifolium' Abdessemed 1981 nom. inval. (Art. 1)

Nomenclatural note: If effectively published, the name Lonicero etruscae-Ilicetum aquifolii cannot be used since none of the eponymous species is a species of the dominant layer. This is a forest community, dominated by Cedrus atlantica.

Lit.: Abdessemed (1981), Meddour \& Géhu (1998).

Abietion maroccano-numidicae Mucina \& Meddour all. nova hoc loco*

Relict Maghrebian fir forests on dolomitic substrates

Holotypus (hoc loco): Asperulo odoratae-Abietetum numidicae Quézel 1956(Quézel, 1956)
Diagnostic taxa: Abies maroccana, A. numidica, Acer opalus s.l., Calamintha grandiflora subsp. baborensis, Doronicum plantagineum subsp. atlanticum, Ilex aquifolium, Myosotis macrocalycina, Paeonia mascula subsp. atlantica. Senecio perralderianus s.1., Taxus baccata

- non Paeonio broteroi-Abietion pinsapo Rivas-Martínez 1982 nom. inval. (Art. 8)

- non Paeonio broteroi-Abietion pinsapo (RivasMartínez 1987) Rivas-Martínez, FernándezGonzález, Loidi, Lousã \& Penas 2002

- incl. Abietenion maroccanae Barbero, Quézel \& Rivas-Martínez 1981 (as suballiance)

Syntaxonomic note: Besides the type association, this also could also contain the Taxus baccatadominated forests (e.g. Meddour \& Laribi, 1999; Gharzouli, 2007).

Asperulo odoratae-Abietetum numidicae Quézel 1956

- 'Associationà Abies numidica et Asperula odorata' Quézel 1956 (orig. form)

- Asperulo odoratae-Adenocarpetum complicati Gharzouli 1989 nom. inval. (Art. 1)

- 'Adenocarpetum complicati-Abietetum munidicae’ Yahi, Médiouni \& Géhu 1999 nom. inval. (Art. 2b)

- 'Asperulo odoratae (Galio odoratae)Abietetum numidicae' Quézel 1956 corr. Gharzouli 2007 nom. inval. (Art. 1; invalid nom. corr.)

Lit.: Quézel (1956), Barbero \& Quézel (1975), Wojterski (1988), Gharzouli (1989, 2007), Kolai (1991), Yahi (1995, 2007), Yahi et al. (1999)

Buxo sempervirentis-Abietetum numidicae Yahi, Médiouni \& Géhu 1999 nom. inval. (Art. 2b)

- Buxo sempervirentis-Abietetum numidicae Meddour \& Géhu 1998 nom. inval. (Art. 2b) Lit.: Meddour \& Géhu (1998), Yahi et al. (1999).

Plagio maghrebini-Quercion canariensis all. nova hoc loco*

Algerian-Tunisian deciduous oak and mixed forests of cold, humid (subhumid) regions on brown forest soils in supramediterranean belt

Holotypus (hoc loco): Plagio maghrebiniQuercetum canariensis Laribi in Meddour ex Meddour, Meddour-Sahar, Zeraia \& Mucina 2017 (hoc loco; see below) 
Diagnostic taxa (* endemic to North Africa): Alliaria petiolata, Cytisus villosus, Doronicum plantagineum subsp. atlanticum*, Drymochloa drymeja, Galium tunetanum, Hedera algeriensis*, Hyacinthoides aristidis*, Lathyrus niger, Laurus nobilis, Melica minuta, Myosotis latifolia, Plagius maghrebinus*, Prunella vulgaris, Prunus avium, Pulicaria odora, Quercus afares*, Q. canariensis, Scutellaria columnae, Teucrium kabylicum* Syntaxonomic note: This new replaces the Iberian Quercion fagineae and the Aceri granatensis-Quercion fagineae in North African mountains. In Algeria, these forests are found in the Tellian Massif along the East Algerian coast. They are distinguished from the Iberian alliances by presence of number of endemic taxa (see above).

- Scutellarion columnae Aimé, Bonin, Chaabane, Loisel \& Saoudi 1986 nom. inval. (Art. 8)

Nomenclatural and syntaxonomic notes: The Tunisian Ilici aquifolio-Quercetum fagineae Aimé et al. 1986 nom. inval. (Art. 5) and the Moehringio pentandraeQuercetum fagineae Aimé, Bonin, Chaabane, Loisel \& Saoudi 1986 nom. inval. (Art. 5) should also belong to this (see Aimé et al., 1986), and therefore the invalidly described Scutellarion columnae Aimé, Bonin, Chaabane, Loisel \& Saoudi 1986 should be synonymised with the Plagio-Quercion canariensis.

- 'Scutellario columnae-Quercion fagineae' (Aimé, Bonin, Chaabane, Loisel \& Saoudi 1986) Meddour 2010 nom. inval. (Art. 8; invalid nom. nov.)

- non Aceri granatensis-Quercion fagineae (Rivas Goday, Rigual \& Rivas-Martínez in Rivas Goday, Borja, Esteve, Galiano, Rigual \& Rivas-Martínez, 1960) RivasMartínez 1987

- non Quercion fagineae Braun-Blanquet, P. Silva \& Rozeira 1956

- non Quercion broteroi Braun-Blanquet, P. Silva \& Rozeira 1956 corr. Rivas-Martínez 1972 (corr. illeg.)

Nomenclatural note: The correction of the original name Quercion fagineae to Quercion broteroi is not legitimate (based on art. 43, as claimed by Rivas-Martínez et al., 2011) because $Q$. broteroi is often understood as a subspecies of $Q$. faginea (see www.emplantbase.org).
- non Quercion fagineo-suberis (BraunBlanquet, P. Silva \& Rozeira 1956) RivasMartínez 1975 nom. illeg. (Art. 29)

\section{Plagio maghrebini-Quercetum canariensis}

Laribi in Meddour ass. nova hoc loco

Holotypus hoc loco: Laribi et al. (2008:

Tab. 3, rel. 5)

Nomenclatural notes: The name-giving species are Q. canariensis and Plagius maghrebinus Vogt \& Greuter (formerly Chrysanthemum fontanesii nom. inval.; see Euro+Med PlantBase). Although the effectively (yet invalidly) published name Chrysanthemo fontanesii-Quercetum canariensis Laribi, Derridj \& Acherar 2008 was published earlier than the invalid name Plagio maghrebini-Quercetum canariensis Laribi in Meddour 2010, the former name cannot be used for validation because it was derived from an invalid taxon name (ICPN art. 2c).

- Chrysanthemo fontanesii-Quercetum canariensis Laribi 2000 nom. inval. (Art. 1)

- Chrysanthemo fontanesii-Quercetum canariensis Laribi, Derridj \& Acherar 2008 nom. inval. (Arts. 2b, 2c \& 5)

- Plagio maghrebini-Quercetum canariensis Laribi 2000 corr. Meddour 2010 nom. inval. (Art. 1; invalid nom. corr.)

- Plagio maghrebini-Quercetum canariensis Laribi in Meddour 2010 nom. inval. (Arts. 5 \& 8)

Lit.: Laribi (2000), Laribi et al. (2008), Meddour (2010), Meddour et al. (2010). Figure 2B.

Viburno tini-Quercetum canariensis ass. nova hoc loco

Holotypus (hoc loco): Meddour (2002: Tab. 7, rel. 6)

- Phillyreo mediae-Quercetum fagineae Aimé, Bonin, Chaabane, Loisel \& Saoudi 1986 nom. inval. (Art. 5)

-Viburno tini-Quercetum canariensis Meddour 2002 nom. inval. (Art. 5).

- non Viburno tini-Quercetum fagineae Torres \& Cano in Cano, Pinto, Valle, Torres, García-Fuentes, Salazar, Melendo \& Mendes 2002

Lit.: Aimé et al. (1986), Hadjadj-Aoul (1988), Meddour (2002).

Epimedio perralderiani-Quercetum fagineae Quézel 1956 
Lit.: Quézel (1956), Aimé et al. (1986), Wojterski (1988), Gharzouli (2007).

\section{Rubo incanescentis-Quercetum fagine- ae Quézel 1956 \\ Lit.: Quézel (1956), Aimé et al. (1986), Meddour (1993, 2010), Laribi (2000), Gharzouli (2007), Laribi et al. (2008), Meddour et al. (2010).}

\section{Lysimachio cousinianae-Quercetum} fagineae Quézel 1956

Lit.: Quézel (1956), Zeraia (1981), Aimé et al. (1986), Khelifi (1987), Khelifi \& Sadki (1995).

Cynosuro peltierii-Quercetum afaredis Laribi in Laribi, Derridj \& Acherar 2008 nom. inval. (Arts. 2b \& 5)

- Cynosuro peltierii-Quercetum afaredis Laribi 2000 nom. inval. (Art. 1)

Lit.: Laribi (2000), Laribi et al. (2008), Meddour et al. (2010).

Quercetum balloto-broteroi ass. nova hoc loco

Holotypus (hoc loco): Alcaraz (1989:

Tab. 1, rel. 11)

Taxonomic note: Quercus faginea subsp. tlemcenensis (A.DC.) Maire \& Weiller ex Greuter \& al. is $Q$. faginea subsp. broteroi (Cout.) A.Camus according to Euro+Med PlantBase.

- 'Groupement à Quercus faginea' (Abdessemed, 1981)

- 'Groupement à Quercus rotundifolia et Quercus faginea subsp. tlemcenensis' (Dahmani, 1984)

- 'Groupements mixtes à Quercus ilex et Quercus faginea subsp. tlemcenensis' (Alcaraz, 1989)

- 'Groupement à Quercus suber et Quercus faginea subsp. baetica' (Miara, 2011)

- 'G1: Quercus rotundifolia-Quercus faginea ssp. tlemcenensis'(Benabdellah, 2011)

Lit:: Abdessemed (1981), Dahmani (1984, 1994), Hadjadj-Aoul (1988), Alcaraz (1989), Benabdellah (2011), Miara (2011), Miara et al. (2012).

Lauro nobilis-Celtidetum australis Bensettiti \& Lacoste 1999 nom. inval. (Art. 2b)

- 'Groupement à Celtis australis' (Monjauze, 1958)

Lit.: Monjauze (1958), Bensettiti (1995), Bensettiti \& Lacoste (1999).
Aceri monspessulani-Ulmetum procerae Meddour 1999

Lit.: Meddour (1999, 2010), Meddour et al. (2010).

\section{Scrophulario laevigatae-Acerion obtusati} all. nova hoc loco*

Submediterranean xero-thermophilous broadleaved scree and ravine maple forests of the Maghreb

Diagnostic taxa: Acer obtusatum, Cystopteris fragilis, Ilex aquifolium, Lonicera etrusca, Polystichum setiferum, Primula acaulis subsp. atlantica, Ruscus aculeatus, Scrophularia laevigata

Holotypus (hoc loco): Scrophulario laevigatae-Aceretum obtusati Wojterski ex Meddour, Meddour-Sahar, Zeraia \& Mucina 2017 (see below)

- Drabo muralis-Acerion obtusati AziraAtroune 2001 nom. inval. (Art. 1)

Syntaxonomic note: The Maghrebian scree forests have been, until today, considered as belonging alliances, characterised either by Quercus canariensis or by Cedrus atlantica. They are, as all scree forest further north (in Europe), distinct through their ecology (nutrient-rich soils subject to downslope erosion) and occurrence in water-rich sheltered habitats (steep slopes of gorges). Floristically they mediate between the mesic-habitat vegetation of Quercus canarensis and alluvial forests. Typically, maples (Acer) and limes (Tilia; missing in North Africa) occur as dominants in these scree forests. The best-known scree is the western-central European Tilio-Acerion Klika 1955. There are several analogous scree alliances in the submediterranean Southern Europe (see Mucina et al., 2016), including the Fraxino excelsioris-Acerion pseudoplatani P. Fukarek 1969 and Ostryo carpinifoliae-Tilion platyphylli (Košir, Čarni \& Di Pietro 2008) Čarni in Willner, Solomeshch, Čarni, Bergmeier, Ermakov \& Mucina 2016 (both Balkan Peninsula), and Tilio pseudorubrae-Ostryion carpinifoliae S. Brullo, Scelsi \& Spampinato 2001 (southern Apennine Peninsula). The position of the Maghrebian Scrophulario laevigataeAcerion obtusati remains contentious. Three options are worth testing, using large-scale syntaxonomic revision: (1) placement of the Scrophulario laevigatae-Acerion obtusati within the Aceretalia pseudoplatani 
(belonging to the Carpino-Fagetea), or (2) description of a new Maghrebian accommodating the new alliance, and finally (3) placement of the Scrophulario laevigatae-Acerion obtusati within the broadly conceived Querco-Cedretalia atlanticae. Since the known scree forests of the Maghreb have been so far classified within the latter, until proven otherwise, we shall follow this option.

Scrophulario laevigatae-Aceretum obtusati Wojterski ass. nova hoc loco Holotypus (hoc loco): Wojterski (1988: 100, Table 32, rel. 1)

- Scrophulario laevigatae-Aceretum obtusati Wojterski 1988 nom. inval. (Art. 5)

- 'Erablière à Acer obtusatum' (Meddour \& Laribi, 1999)

Lit.: Wojterski (1988), Meddour (1994a, 2002), Meddour \& Géhu (1998), Meddour \& Laribi (1999).

Prunetum avii Toubal 1998 nom. inval. (Art. 1).

- 'Groupement à Prunus avium' (Wojterski, 1988)

- 'Groupement à Prunus avium' (Bensettiti, 1995)

Lit.: Wojterski (1988), Bensettiti (1995), Toubal (1998).

\section{Cystopterido fragilis-Aceretum} obtusati Azira-Atroune 2001 nom. inval. (Art. 1)

Lit.: Azira-Atroune (2001).

Cotyledoni brevifoliae-Aceretum obtusati Azira-Atroune 2001 nom. inval. (Art. 1)

Lit.: Azira-Atroune (2001).

Linario rubrifoliae-Aceretum campestris Azira-Atroune 2001 nom. inval. (Art. 1)

Lit.: Azira-Atroune (2001).

Crataego-Prunetea Tüxen 1962 nom. conserv. propos.

Scrub and mantle vegetation seral or marginal to broad-leaved forests in the nemoral zone and the submediterranean regions of Europe Syntaxonomic note: Aymonin (1963) could have been the one who identified for the first time in Algeria (and in North Africa) plant communities for resembling this class. Although not directly addressing the class, he had noticed a "spiny formation, very closed, of secondary origin, appearing in coppice at Rosaceae (Crataegus, Prunus), with Rhamnus alaternus, Viburnum tinus, Lonicera implexa and Rubus" in the Cherchellois area (Eastern Algeria). This observation was later confirmed by Wojterski (1988), Meddour (1994) and Géhu et al. (1994). For Quézel \& Médail (2003a; see also Meddour, 2010), the vegetation belonging to this in the Maghreb is still rather poorly known.

- Rhamno catharticae-Prunetea spinosae Rivas Goday \& Borja ex Tüxen 1961 nom. inval. (Art. 3b) - Rhamno-Prunetea Rivas Goday et Borja Carbonell ex Tüxen 1962 nom. inval. (Art. 3b) Nomenclatural note: Mucina et al. (2016: 45) suggested (informally) conservation of the Crataego-Prunetea Tüxen 1962 against less often used (validly published) Sambucetea Doing 1962.

Pyro spinosae-Rubetalia ulmifolii Biondi, Blasi \& Casavecchia in Biondi, Allegrezza, Casavecchia, Galdenzi, Gasparri, Pesaresi, Vagge \& Blasi 2014

Spiny bramble scrub on nutrient-rich soils of the winter-mild Atlantic seaboards, the Mediterranean, the Macaronesian Archipelago and the Azores

Pruno spinosae-Rubion ulmifolii $O$. de Bolòs 1954

Spiny bramble scrub of the winter-mild Atlantic seaboards and the Western Mediterranean of Europe and North Africa

Tamo communis-Crataegetum monogynae Meddour 1998 nom. inval. (Art. 1)

Lit.: Meddour (1994a, 1998, 2002).

Comm. 'Haie à Crataegus monogyna' (Wojterski, 1988)

Lit.: Wojterski (1988, 1990), Meddour (2002).

Comm. 'Groupement à Rubus ulmifolius' (Wojterski, 1988)

- 'Fruticée à Rubus ulmifolius' (Meddour \& Laribi, 1999)

Lit.: Wojterski (1988, 1990), Géhu et al. (1994a), Meddour \& Laribi (1999). 


\section{AZONAL FORESTS AND SCRUB}

Alno glutinosae-Populetea albae P. Fukarek \& Fabijanić 1968

Riparian gallery forests of the Eurosiberian and Mediterranean Regions

Populetalia albae Braun-Blanquet ex Tchou 1949

Mediterranean and submediterranean riparian gallery forests

Clematido cirrhosae-Populion albae

Bensettiti \& Lacoste all. nova hoc loco*

Thermomediterranean deciduous alluvial willow-poplar forests along in summer often dry rivers of the Maghreb

Holotypus (hoc loco): IridofoetidissimaePopuletum albae Nègre 1964 (Nègre 1964: 13-14)

Diagnostic species: Aristolochia sempervirens, Arundo donax (natura-lised in the Western Mediterranean), Clematis cirrhosa, Iris foetidissima, Populus alba

Nomenclatural note: Bensettiti \& Lacoste (1999) called this informally Populion albae "méridional".

- Clematido cirrhosae-Populion albae Bensettiti \& Lacoste 1999 nom. inval. (Art. 5)

- non Populion albae Braun-Blanquet 1930 (phantom)

- non Populion albae Braun-Blanquet 1931 nom. inval. (Art. 8)

- non Populion albae Tüxen 1931 nom. inval. (Art. 8)

- non Populion albae de BannesPuygiron 1933 nom. inval. (Art. 8)

- non Populion albae Szafer in Soó 1941 nom. inval. (Art. 8)

- non Populion albae Braun-Blanquet \& Tüxen 1943 nom. inval. (Art. 8)

- non Populion albae Braun-Blanquet 1948 nom. inval. (Art. 8)

- non Populion albae Braun-Blanquet ex Tchou 1949

- non Saponario officinalis-Populion albae (Braun-Blanquet 1931) Bensettiti \& Lacoste 1999 nom. inval. (Art. 8) Nomenclatural note: Bensettiti \& Lacoste's (1999) 'Populion albae "septentrional" = Saponario-Populion' is de facto a nomen novum introduced for the Populion albae
Braun-Blanquet 1931 nom. inval., and therefore invalid as well.

Irido foetidissimae-Populetum albae Nègre 1964

- 'Groupement à Populus alba' (Rebbas et al., 2011)

- non Irido foetidissimae-Populetum albae (Braun-Blanquet ex Tchou 1948) O. de Bolòs 1962 nom. inval. (Art. 1; invalid nom. nov.)

Nomenclatural note: De Bolòs (1962) attempted renaming the Tchou's association, however cited wrong year (1948); the effective year of publication of the 'Populetum albae', that was subject of renaming, is 1949. However, even if this technicality would not be an acceptable, the name Irido foetidissimae-Populetum albae has been already taken (Nègre 1964), hence the de Bolòs' (1962) name would become a later homonym (Art. 31).

- non Populetum von Soó 1927 nom. inval. (Art. 2b)

- non Populetum albae de Soó 1929 nom. inval. (Art. 2b)

- non Irido foetidissimae-Populetum albae Braun-Blanquet ex Tchou 1947 (phantom)

- non Irido foetidissimae-Populetum albae Braun-Blanquet ex Tchou 1948 (phantom)

- non Populetum albae BraunBlanquet ex Tchou 1949

Lit.: Nègre (1964), Bensettiti (1985, 1992, 1995), Wojterski (1988), Wojterski \& Bensettiti (1988), Bensettiti \& Lacoste (1999), Kaabèche et al. (1995), Rebbas et al. (2011).

\section{Salici pedicellatae-Fraxinion angustifoliae} all. nova hoc loco*

Maghrebian high-elevation (meso- to supramediterranean) riparian ash-dominated forests

Holotypus (hoc loco): Equiseto maximiFraxinetum angustifoliae Bensettiti \& Lacoste ex Meddour, Meddour-Sahar, Zeraia \& Mucina 2017 (see below)

Diagnostic species: Alliaria petiolata, Apium nodiflorum, Celtis australis, Clinopodium vulgare, Fraxinus angustifolia, Ilex aquifolium, Lamium flexuosum, Polystichum setiferum, Prunus avium, Salix pedicellata 
Nomenclatural note: The description of this new is not an upranking of the sub Salici pedicellatae-Fraxinion angustifoliae Bensettiti \& Lacoste 1999 since this sub was not validly described (Art. 5).

- non Lauro nobilis-Fraxinion angustifoliae

I. Kárpáti \& V. Kárpáti 1961

- non Fraxinion angustifoliae Pedrotti 1970 nom. inval. (Art. 3b)

- non Fraxinion angustifoliae Pedrotti ex Biondi \& Casavecchia in Biondi, Casavecchia \& Pesaresi 2010 nom. inval. (Art. 5)

- non Carici remotae-Fraxinion oxycarpae Pedrotti ex Pedrotti, Biondi, Allegrezza \& Casavecchia in Biondi, Allegrezza, Casavecchia, Galdenzi, Gasparri, Pesaresi, Vagge \& Blasi 2014

- non Lauro nobilis-Ulmion minoris Biondi, Casavecchia, Gasparri \& Pesaresi in Biondi, Allegrezza, Casavecchia, Galdenzi, Gasparri, Pesaresi, Vagge \& Blasi 2014

Equisetomaximi-Fraxinetum angustifoliae Bensettiti \& Lacoste ass. nova hoc loco

- Equiseto maximi-Fraxinetum angustifoliae Bensettiti \& Lacoste 1999 nom. inval. (Art. 5)

- Holotypus (hoc loco): Bensettiti \& Barbero (2009: Table 4, rel. 1)

- Nomenclatural note: Because the original (invalid) description of the association (Bensettiti \& Lacoste, 1999) contains only a synthetic (constancy) table, a neotype had to be selected.

- 'Carici-Fraxinetum' (sensu auct. maghrebianum)

- non Carici-Fraxinetum excelsioris Koch ex Faber 1936

- non Carici-Fraxinetum angustifoliae Pedrotti 1970

- non Carici-Fraxinetum angustifoliae Jovanović \& Tomić 1979

- non Carici-Fraxinetum angustifoliae Piccoli \& Gerdol 1984

- non Carici-Fraxinetum oxycarpae Pedrotti 1970 corr. 1992 (corr. superfl.)

Nomenclatural note: The correction of the name Carici-Fraxinetum angustifoliae Pedrotti 1990 by Pedrotti (1992) is superfluous since Fraxinus oxycarpa Willd. is considered basionym of Fraxinus angustifolia subsp. oxycarpa (Willd.) Franco \& Rocha Afonso (see Euro+Med PlantBase) and hence either misiden- tification or taxonomic homonymy do not apply.

Lit.: Wojterski \& Bensettiti in Wojterski (1988), Wojterski \& Bensettiti (1988), Bensettiti (1995), Bensettiti \& Lacoste (1999), Bensettiti \& Barbero (2009).

Salici pedicellatae-Populetum nigrae Bensettiti \& Lacoste 1999 nom. inval. (Arts. 2b \& 5)

Lit.: Bensettiti \& Lacoste (1999).

Comm. 'Groupement à Ulmus campestris et Fraxinus angustifolia' (Bensettiti, 1985)

Lit.: Bensettiti(1985, 1992, 1995), Wojterski

\& Bensettiti in Wojterski (1988), Kaabèche et al. (1995).

Comm. 'Groupement à Salix alba et Fraxinus angustifolia' (Géhu et al., 1994)

Lit.: Géhu et al. (1994a).

Comm. 'Galeries forestières à orme (Ulmus campestris var. suberosa)' (Wojterski, 1988)

Lit.: Wojterski (1988).

Osmundo-Alnion glutinosae (BraunBlanquet, P. Silva \& Rozeira 1956) Dierschke \& Rivas-Martínez in Dierschke 1975

Alder and willow riparian forests of the Western Mediterranean

Scrophulario tenuipedis-Alnetum glutinosae Meddour \& Laribi 1999

Lit.: Meddour \& Laribi (1999), Laribi (2000), Meddour et al. (2010).

Lamio flexuosi-Alnetum glutinosae O. de Bolòs 1954 nom. invers. propos.

- Lamio flexuosi-Alnetum glutinosae Bensettiti \& Lacoste 1999 nom. inval. (Art. 2b)

Lit.: Bensettiti (1995), Bensettiti \& Lacoste (1999), Bensettiti \& Barbero (2009), Belouahem-Abed (2012).

Salicetea purpureae Moor 1958

Willow and tamarisk scrub and low open forests of riparian habitats in the temperate to arctic zones of Europe

Salicetalia pupureae Tüxen 1937

Willow scrub and low open forests of riparian habitats in the temperate to arctic zones of Europe 
Salicion triandrae Müller \& Görs 1958

Willow scrub on loamy-sandy sedimentary river banks in the lowland to submontane belts of the nemoral zone of Europe

Comm. 'Groupement à Salix purpurea' (Kaabèche et al., 1995)

Lit.: Kaabèche et al. (1995), Géhu et al. (1998).

\section{Salicion albae Soó 1951}

Willow and poplar low open forests of lowland to submontane river alluvia in the nemoral zone of Europe and at high altitudes of the Mediterranean

Comm. 'Groupement à Salix alba' (Kaabèche et al., 1995)

Lit.: Kaabèche et al. (1995), Géhu et al. (1998).

Alnetea glutinosae Braun-Blanquet \& Tüxen ex Westhoff, Dijk \& Passchier 1946

European and North African mesotrophic regularly flooded alder carr and birch wooded mires

- Alnetea glutinosae Braun-Blanquet \& Tüxen 1943 (Art. 2b)

Alnetalia glutinosae Tüxen 1937

European and North African mesotrophic regularly flooded alder carr

Campanulo alatae-Alnion glutinosae all. nova hoc loco*

North African mesotrophic regularly flooded alder carr

Holotypus (hoc loco): Viti viniferaeAlnetum glutinosae Meddour, Meddour-Sahar, Zeraia \& Mucina 2017 (see below)

Diagnostic taxa: Alnus glutinosa, Allium triquetrum, Apium nodiflorum, Arum italicum, Campanula alata, Carex pendula, C. remota, Laurus nobilis, Ruscus hypophyllum, Vitis vinifera subsp. sylvestris

- non Alnion glutinosae Malcuit 1929 Syntaxonomic note: The description of this is not an up-ranking of the suballiance Campanulo alatae-Alnenion glutinosae Bensettiti \& Lacoste 1999 because the latter syntaxon was published invalidly (Arts. 5 \& 8). This North African comprises remarkable southern outliers of wooded mires experiencing several months of waterlogging under summer-hot, humid Mediterranean climate (Bensettiti, 1992; Bensettiti \& Lacoste, 1999). The 'Carici remotaeAlnetum glutinosae' Debazac 1959, described from Tunisia (Debazac, 1959: 77), might belong here as well.

Viti viniferae-Alnetum glutinosae ass. nova hoc loco

Holotypus (hoc loco): Géhu et al. (1994: Table 1, rel. 7)

- Ruscohypophylli-Alnetumglutinosae Géhu, Kaabèche \& Gharzouli 1994 nom. inval. (Art. 3f)

Nomenclatural note: Géhu et al. (1994b) chose an unfortunate name for this association listing Ruscus hypoglossum (occurring in only one of seven relevés) as an eponymous species. Since this species is not found in the holotype (Table 1, rel. 2) assigned by Géhu et al. (1994b), the association name is deemed invalid.

- Rubo caesii-Alnetum glutinosae Bensettiti 1995 nom. inval. (Art. 1)

- Rubo caesii-Alnetum glutinosae Bensettiti \& Lacoste 1999 nom. inval. (Arts. 2b \& 5)

- Rubo caesii-Alnetum glutinosae Bensettiti in Meddour \& Laribi 1999 nom. inval. (Arts. 2b \& 5)

- non Carici pendulae-Alnetum glutinosae Braun-Blanquet 1967

- non Lauro nobilis-Alnetum glutinosae Brullo \& Guarino 1998

Lit.: Bensettiti (1992, 1995), Géhu et al. (1994a, b), Bensettiti \& Lacoste (1999), Belouahem-Abed et al. (2011).

Franguletea Doing ex Westhoff in Westhoff \& Den Held 1969

Willow carr of Western Europe, Fennoscandia, the subatlantic regions of Central Europe and North Africa

Salicetalia auritae Doing 1962

Willow carr of Western Europe, Fennoscandia, the subatlantic regions of Central Europe and North Africa 
Tamo communis-Salicion atrocinereae de Foucault \& Julve ex Mucina \& Meddour all. nova hoc loco

Willow carr of Atlantic coastal regions of southwestern France, Iberian Peninsula and North Africa

Holotypus (hoc loco): Tamo communisSalicetum acuminatae de Foucault 1995 (de Foucalt, 1995: 61, Tab. 17)

Diagnostic taxa: Arum italicum, Dioscorea communis, Laurus nobilis, Ruscus hypophyllum, Salix cinerea subsp. oleifolia (= S. atrocinerea)

- Tamo communis-Salicion atrocinereae de Foucault \& Julve 2001 nom. inval. (Art. 5)

Nomenclatural note: De Foucault \& Julve (2001) classified three, all validly described, associations in this alliance, namely: Tamo communis-Salicetum acuminatae de Foucault 1995, Viti viniferae-Salicetum acuminatae Rivas-Martínez \& Costa in Rivas-Martínez, Costa, Castroviejo \& Valdes 1980, Clematidi campanulifloraeRubetum ulmifolii Peinado \& Velasco in Peinado, Moreno \& Velasco 1983 (this association actually belongs to the PrunoRubion ulmifolii). De Foucault \& Julve (2001) have, however, failed to designate the holotype and therefore we validate the here.

- non Salicion cinereae T. Müller \& Görs ex Passarge 1961

Syntaxonomic and nomenclatural notes: The Tamo communis-Salicion atrocinereae is a warm-temperate (South EuropeanNorth African) geographic analogon of the European boreo-temperate Salicion cinereae, and it differs from the latter by its diagnostic taxa (see above).

Rusco hypophylli-Salicetum atrocinereae Géhu, Kaabèche \& Gharzouli 1994

Syntaxonomic note: This is, so far, the only association of the willow carrs described from North Africa, exemplifying a unique occurrence of this habitat and vegetation type outside of Eurasia. In the region where this association was described there is the only site of Frangula alnus in Algeria (Belouahem-Abed et al., 2011). This species is also found across the Algerian border in
Tunisian Kroumiria (Nègre, 1952; Debazac, 1959; Timbal, 1970).

Lit.: Géhu et al. (1994b, 1998).

Nerio-Tamaricetea Braun-Blanquet \& O. de Bolòs 1958

Circummediterranean and Macaronesian riparian scrub

Tamaricetalia africanae Braun-Blanquet \& O. de Bolòs 1958

Circummediterranean and Macaronesian riparian scrub

- Nerio oleandri-Viticetalia agni-casti de Foucault, Bensettiti, Noble \& Paradis 2012 (syntax. syn.)

Tamaricion africanae Braun-Blanquet \& O. de Bolòs 1958

Infra- to supramediterranean tamarisk riparian scrub in temporarily flooded freshwater habitats of the Western Mediterranean

Nerio oleandri-Tamaricetum africanae Kaabèche, Gharzouli \& Géhu ex Mucina \& Meddour ass. nova hoc loco Holotypus (hoc loco): Kaabèche et al. (1995: table 11, rel. 2)

- Nerio oleandri-Tamaricetum africanae Kaabèche, Gharzouli \& Géhu 1995 nom. inval. (Art. 5)

- 'Groupement à Nerium oleander et Tamarix africana' (Toubal, 1986)

Lit.: Toubal (1986), Géhu et al. (1994a, 1998), Kaabèche et al. (1995), de Foucault et al. (2012).

Comm. 'Groupement à Tamarix africana' (Wojterski \& Bensettiti in Wojterski, 1988)

Lit.: Wojterski \& Bensettiti in Wojterski (1988), Bensettiti (1995), Géhu et al. (1994a, 1998).

Tamaricion boveano-canariensis Izco, Fernández-González \& Molina 1984 Infra- to supramediterranean tamarisk riparian scrub in temporarily flooded brackish habitats of the Western Mediterranean and Macaronesia

Comm. 'Groupement à Tamarix boveana'(Dubuis \& Simonneau, 1954) Lit.: Dubuis \& Simonneau (1954), De Foucault et al. (2012).

Rubo ulmifolii-Nerion oleandri $O$. de Bolòs 1985 
Thermo- to supramediterranean oleander riparian scrub of the Western Mediterranean.

Rubo ulmifolii-Nerietum oleandri $\mathrm{O}$. de Bolòs 1956

Lit.: Sadki (1988), Khelifi \& Sadki (1995), Géhu et al. (1998), de Foucault et al. (2012).

Lavatero olbiae-Rubetum ulmifolii Farris, Secchi \& Filigheddu 2007

- Lavatero olbiae-Rubetum ulmifolii Rebbas 2002 nom. inval. (Art. 1)

- 'Groupement à Lavatera olbia et Rubus ulmifolius'(Rebbas et al., 2011).

Lit.: Rebbas (2002), Rebbas et al. (2011).

\section{Outlook}

In Algeria, the most variable forest and scrub is the Quercetea ilicis, a flagship syntaxonomic unit of the Mediterranean vegetation as it comprises 65 associations (nearly $51 \%$ of the entire count). This is also well represented in the neighbouring Morocco (Quézel \& Barbero, 1986; Fennane, 2003) and Tunisia. The syntaxonomic contents of this class, and especially of the Pistacio lentisci-Rhamnetalia alaterni remains a matter of concern. The syntaxonomic status of many alliances of this is well-defined in the Iberian Peninsula, France and Italy (Rivas-Martínez et al., 2001, 2002; Bardat et al., 2004; Costa et al., 2012; Biondi et al., 2014; see also Mucina et al., 2016). However, as highlighted by Benabid \& Fennane (1994) and Fennane (2003), the delimitation of the alliances within this (9 alliances in case of our synopsis) is not clear and a critical revision of these concepts in North Africa is urgently needed.

The oak and cedar forests of the Quercetea pubescentis, incl. the iconic cedar forests of the Atlas classified in the Querco-Cedretalia atlanticae, appears as the second most important as it includes 35 associations (27\% of the count). The oak and cedar forests are of high patrimonial significance and deserve protection.

Finally, the Junipero-Pinetea sylvestris (represented by a North African endemic - the Ephedro majoris-Juniperetalia phoeniceae), is the third zonal forest/scrub found in Algeria. The 6 associations (or plant communities) of this are representives of this Mediterranean montane vegetation as known from the Iberian Peninsula $(\mathrm{Ju}$ niperetalia hemisphaericae; Rivas-Martínez et al., 1999) and the Eastern Mediterranean (Brullo et al., 2001; see also Mucina et al., 2016 for the formal description of the new Berberido creticae-Juniperetalia excelsae). The high-altitude juniper-dominated scrub and open woodlands have been considered 'presteppic forest type' (e.g. Jørgensen, 2009), hence definitely different from the mediterranean, prevalently low-altitude oak forest (woodland) and scrub of the Quercetea ilicis. The peculiarity of this vegetation (and its distinctness from other forest vegetation types of North Africa) has been recognised by Quézel \& Barbero (1981), who described a class in its own right (Ephedro majoris-Juniperetea phoeniceae Quézel \& Barbero 1981) to accommodate this vegetation concept.

Besides these zonal units, the azonal forest vegetation limited to alluvial riverine habitats (oueds) supports notable 8 associations of riparian forest classified within the mediterranean Populetalia albae (Alno glutinosae-Populetea albae). These forests are of national significance due to important ecological services they render in the Algerian valley-dominated landscapes, hydrology, and biodiversity (see also Quézel \& Médail, 2003b).

Our synopsis is poised to become an important tool fostering intensification of surveying of vegetation (and biodiversity, in general) resources in Algeria. In comparison with neighbouring Morocco, where the checklist of the forest and scrub vegetation includes 2 classes, 5 orders, 13 alliances, and 124 associations (Fennane, 2003), our synopsis demonstrates a higher level of completeness.

It is regretable that the number of phytosociological studies in Algeria has decreased in the last years. This is a worrying trend that has to be reversed if the variability of the Algerian vegetation is to be revealed and understood in order to secure sustainable use and protection of this valuable national resource.

\section{Acknowledgements}

We want to thank to our Algerian colleagues, in particular to F. Azira-Atroune, S. Hadjadj-Aoul, L. Kadik and M. Laribi, as well as Z. Lososová and R. Gavilán kindly provided some less accessible literature. Jean-Paul Theurillat kindly advised with some nomenclatural issues. R. Gavilán kindly translated our abstract and keywords into Spanish. L.M. acknowledges the logistic support of the Iluka Chair at The University of Western Australia. 


\section{References}

Aafi, A. 2007. Etude de la diversité floristique de l'écosystème de chêne-liège de la forêt de la Mamora. Mem. Doc. (ined.). Univ. Aix-Marseille III.

Abdessemed, K. 1981. Le Cèdre de l'Atlas (Cedrus atlantica Manetti) dans les massifs de l'Aurès et du Bélezma. Etude phytosociologique, problèmes de conservation et d'aménagement. Mem. Doc. (ined.). Univ. Aix-Marseille III.

Abdessemed, K. 1984. Les relations climat-végétation dans le Sud Constantinois. Bull. Soc. Bot. France 131: $145-155$.

Aimé, S., Ainad-Tabet, L., Hadjadj-Aoul, S. \& Sebaa, E.D. 1983. Recherches phytoécologiques en Oranie. Premiers résultats. Mém. Soc. Hist. Nat. Afr. Nord N.S. 13: 17-31.

Aimé, S., Bonin, G., Chaabane, A., Loisel, R. \& Saoudi, H. 1986. Notes phytosociologiques nord-africaines. Contribution à l'étude phytosociologique des zénaies du littoral algéro-tunisien. Ecol. Medit. 12(3-4): 113-131.

Alcaraz, C. 1989. Contribution à l'étude des groupements à Quercus ilex et Quercus faginea subsp. tlemcenensis des monts de Tlemcen (Algérie). Ecol. Medit. 15(3-4): 15-32.

Alcaraz, C. 1991. La tétraclinaie sur terra rossa en sous-étage semi-aride supérieur chaud. TH2: Groupement à Tetraclinis articulata et Rhus pentaphylla (variante thermophile). Mediterranea, Ser. Biol., 13: 91-104.

Amara, M. 2014. Contribution à l'étude des groupements à Pistacia atlantica subsp. atlantica dans le NordOuest algérien. Mem. Doc. (ined.). Univ. Tlemcen.

Asensi, A., Diez-Garretas, B. \& Quézel, P. 2007. Plant communities of Juniperus turbinata Guss. subsp. turbinata in the Mediterranean Region. A biogeographical, bioclimatical and syntaxonomical survey. Phytocoenologia 37: 599-623.

Aymonin, G.G. 1963. Observations et remarques sur le paysage végétal du Cherchellois (Algérie). Bull. Soc. Bot. France 110(9): 390-392.

Azira-Atroune, F. 2001. Etude syntaxonomique des groupements à Erables du centre algérien (parcs nationaux du Djurdjura, des Babors et de Theniet el Had). Mem. Doc. (ined.). Univ. Bab Ezzouar, Alger.

Barbero, M., Loisel, R. \& Quézel, P. 1974. Problèmes posés par l'interprétation phytosociologique des Quercetea ilicis et des Quercetea pubescentis. Coll. Intern. CNRS 235: 481-197.

Barbero, M. \& Quézel, P. 1975. Les forêts de sapins sur le pourtour méditerranéen. An. Inst. Bot. Cavanilles 32: 1245-1289.

Barbero, M., Quézel, P. \& Rivas-Martínez, S. 1981. Contribution à l'étude des groupements forestiers et préforestiers du Maroc. Phytocoenologia 9: 311-412.

Barbero, M., Lebreton, P. \& Quézel, P. 1994. Sur les affinités biosystématiques et phytoécologiques de Juniperus thurifera et Juniperus excelsa Bieb. Ecol. Medit. 20(3-4): 21-37.

Bardat, J., Bioret, F., Botineau, M., Boullet, V., Delpech, R., Géhu, J.-M., Haury, J., Lacoste, A., Rameau, J.C., Royer, J.M., Roux, G. \& Touffet, J. 2004. Prodrome des végétations de France. Mus. Nat. Hist. Nat., Paris.

Bartolo, G., Brullo, S. \& Marcenò, C. 1982. La vegetazione costiera della Sicilia sud-orientale. Contributo alla interpretazione delle fasce di vegetazione delle coste mediterranee. Quad. C.N.R., Ser. AQ/1/226, 1-49.

Baumgartner, N. 1966. Etude phytosociologique des massifs forestiers du Sahel de Tipasa. Bull. Soc. Hist. Nat. Afr. Nord 56: 98-164.

Beghami, Y. 2013. Ecologie et dynamique de la végétation de l'Aurès: analyse spatio-temporelle et étude de la flore forestière et montagnarde. Mem. Doc. (ined.). Univ. Biskra.

Belouahem-Abed, D. 2012. Étude écologique des peuplements forestiers des zones humides dans les régions de Skikda, Annaba et El-Tarf (Nord-Est algérien). Mem. Doc. (ined.). Univ. Annaba.

Belouahem-Abed, D., Belouahem, F., Benslama, M., De Bélair, G. \& Muller, S.D. 2011. Les aulnaies de la Numidie (NE Algérien): biodiversité floristique, vulnérabilité et conservation. C.R. Biol. 334: 61-73.

Benabdellah, M.A. 2011. Analyse phytoécologique des groupements à thuya (Tetraclinis articulata (Vahl) Masters) et à chêne vert (Quercus rotundifolia Lam.) dans les monts de Tlemcen (Algérie occidentale). Mem. Doc. (ined.). Univ. Abou Bekr Belkaid, Tlemcen.

Benabdelli, K. 1996. Mise en évidence de l'importance des formations basses dans la sauvegarde des écosystèms forestiers: cas des monts de Dhaya (Algérie occidentale). Ecol. Medit. 22(3-4): 101-112. 
Benabid, A. 2000. Flore et écosystèmes du Maroc. Evaluation et préservation de la biodiversité. Ibis Press, Paris.

Benabid, A. \& Fennane, M. 1994. Connaissances sur la végétation du Maroc: phytogéographie, phytosociologie et séries de végétation. Lazaroa 14: 21-97.

Bensettiti, F. 1985. Etude phytosociologique des forêts riveraines à peuplier blanc (Populus alba L.) dans l’Algérois. Mem. Doc. (ined.). Inst. Nat. Agron., Alger.

Bensettiti, F. 1992. Approche phytosociologique des aulnaies de la région d'El Kala (Algérie). Doc. Phytosociol. N.S. 14: 231-240.

Bensettiti, F. 1995. Contribution à l'étude phytosociologique des ripisylves du Nord de l'Algérie. Essai de synthèse à l'échelle de la Méditerranée occidentale. Mem. Doc. (ined.). Univ. Paris-Sud.

Bensettiti, F. \& Lacoste, A. 1999. Les ripisylves du nord de l'Algérie: essai de synthèse synsystématique à l'échelle de la Méditerranée occidentale. Ecol. Medit. 25(1): 13-39.

Bensettiti, F. \& Barbero, M. 2009. Les frênaies thermophiles à Fraxinus angustifolia un habitat d'intérêt communautaire (UE 91B0) du sud de la France. Présentation et synthèse à l'échelle du domaine méditerranéen. Rapport SPN 2009/06. MNHN-DEGB/SPN, Paris.

Biondi, E., Blasi, C., Allegrezza, M., Anzellotti, I., Azzella, M.M., Carli, E., Casavecchia, S., Copiz, R., Del Vico, E., Facioni, L., Galdenzi, D., Gasparri, R., Lasen, C., Pesaresi, S., Poldini, L., Sburlino, G., Taffetani, F., Vagge, I., Zitti, S. \& Zivkovic, L. 2014. Plant communities of Italy: The Vegetation Prodrome. Plant Biosyst. 148: 728-814.

Boulaacheb, N. 2009. Etude de la végétation terrestre et aquatique du djebel Megriss (Nord Tellien, Algérie). Analyse floristique, phytosociologique et pastorale. Mem. Doc. (ined.). Univ. Ferhat Abbas, Sétif.

Boussouf, L. 2004. Contribution à l'étude phytoécologique et phytosociologique de quelques groupements préforestiers de dégradation dans l'Atlas Blidéen (secteur algérois). Mem. Doc. (ined.). Univ. Bab Ezzouar, Alger.

Brakchi, L. 1998. Etude phytoécologique et phytosociologique du Pin d'Alep dans le secteur algérois. Mem. Doc. (ined.). Univ. Bab Ezzouar, Alger.

Braun-Blanquet, J. 1964. Pflanzensoziologie. Grundlagen der Vegetationsforschung. 3. Ed. Springer-Verlag, Wien.

Braun-Blanquet, J., Font Quer, P. Braun-Blanquet, G. Frey, E. Jansen, P. \& Moor, M. 1936. L'Excursion de la Sigma en Catalogne (Pâques 1934). Cavanillesia 7: 153-167.

Brullo, S. \& Marcenò, C. 1985 ('1984'). Contributo alla conoscenza della classe Quercetea ilicis in Sicilia. Notiz. Fitosociol. 19: 183-229.

Brullo, S., Giusso del Galdo, G. \& Guarino, R. 2001. The orophilous communities of the Pino-Juniperetea in the Central and Eastern Mediterranean area. Feddes Repert. 112: 261-308.

Brullo, S., Gianguzzi, L., La Mantia, A. \& Siracusa, G. 2008. La classe Quercetea ilicis in Sicilia. Boll. Accad. Gioenia Sci. Nat. 41, 369: 1-80.

Chermat, S. 2014. Etude phytosociologique et pastorale des djebels Youssef et Zdimm (Hautes plaines Sétifiènnes). Mem. Doc. (ined.). Univ. Ferhat Abbas, Sétif.

Chevassut, G., 1956. Les groupements végétaux du marais de la Rassauta. An. Inst. Agr. Alger. 10(4): 1-96.

Costa, J.C., Neto, C., Aguiar, C., Capelo, J., Espírito-Santo, D., Honrado, J., Pinto Gomes, C., Monteiro-Henriques, T., Sequeira, M. \& Lousã, M. 2012. Vascular plant communities in Portugal (continental, the Azores and Madeira). Glob. Geobot. 2: 1-180.

Dahmani, M. 1984. Contribution à l'étude des groupements de Chêne vert (Quercus rotundifolia Lamk.) des monts de Tlemcen (Ouest algérien): approche phytoécologique et phytosociologique. Mem. Doc. (ined.). Univ. Bab Ezzouar, Alger.

Dahmani, M. 1994. Les groupements à chêne vert en Algérie: signification syntaxonomique et bioclimatique. An. Inst. Super. Agron. 44: 351-367.

Dahmani-Megrerouche, M. 1996a. Diversité biologique et phytogéographique des chênaies vertes d'Algerie. Ecol. Medit. 22(3-4): 19-38.

Dahmani-Megrerouche, M. 1996b. Les groupements à chêne vert et étages de végétation en Algerie. Ecol. Medit. 22(3-4): 39-52.

Dahmani-Megrerouche, M. 1997. Le chêne vert en Algérie. Syntaxonomie, phytoécologie et dynamique des peuplements. Mem. Doc. (ined.). Univ. Bab Ezzouar, Alger. 
Dahmani-Megrerouche, M. \& Loisel, R. 2003. Contribution à l'étude des groupements à chêne vert forestiers et préforestiers en Algérie. Doc. Phytosociol. N.S. 20: 23-87.

Dahmani-Megrerouche, M., Achoubi-Kadik, L., Yahi, N., Atroune, F., Boussouf, L., Brakchi, L., Bouaoune, D. \& Sadki, N. 2014. Contribution à la mise en place d'un cadre syntaxonomique pour les groupements forestiers et préforestiers de l'Algérie du Nord. Doc. Phytosociol., Sér. 3, 1: 487-499.

Debazac, E.F. 1959. La végétation forestière de la Kroumirie. Ann. E.N.E.F. 16(2): 1-131.

De Bélair, G., Chessel, D. \& Bencheikh-Lehocine, M. 1984. Structure spatiale et statut dynamique dans une communauté végétale: cas d'une cocciféraie dunaire (Annaba, Algérie). Ecol. Medit. 10(1-2): 261-270.

De Bélair, G. \& Bencheikh-Lehocine, M. 1987. Composition et déterminisme de la végétation d'une plaine côtière marécageuse: La Mafragh (Annaba, Algérie). Bull. Ecol. 18: 393-407.

De Bolòs, O. 1962. El paisaje vegetal barcelonés. Fac. Filosofía Letras. Univ. Barcelona, Barcelona.

De Foucault, B. 1995. Contribution à une monographie phytosociologique de la Hague (Manche, France). Bull. Soc. Bot. Nord France 48(4): 45-90.

De Foucault, B. \& Julve, P. 2001. Syntaxonomie der Strauchgesellschaften der Rhamno catharticae-Prunetea spinosae Rivas-Goday, Borja-Carbonell 1961 in Europa. Verh. Zool.-Bot. Ges. Österr. 138: 177-243.

De Foucault, B., Bensettiti, F., Noble, V. \& Paradis, G. 2012. Contribution au prodrome des végétations de France: les Nerio oleandri-Tamaricetea africanae Braun-Blanq. \& O. de Bolòs 1958. J. Bot. Soc. Bot. France 58: 41-54.

Djaaboub, S. 2008. Etude de la végétation du lac Bleu (Parc National d'El-Kala) phytoécologie, phytosociologie et cartographie. Mem. Doc. (ined.). Inst. Nat. Agron., Alger.

Djebaïli, S. 1978. Recherches phytosociologiques et écologiques sur la végétation des hautes plaines steppiques et de l'Atlas Saharien algérien. Mem. Doc. (ined.). Univ. Montpellier.

Djebaïli, S. 1984. Steppe algérienne. Phytosociologie et écologie. Offices des Publications Universitaires, Algiers.

Djebaïli, S. 1990. Syntaxonomie des groupements préforestiers et steppiques de l'Algérie aride. Ecol. Medit. 16: 231-244.

Djebaïli, S. 1994. Les groupements forestiers de l'Algérie humide et subhumide (synthèse mettant en relief la répartition des unités syntaxonomiques dans les étages de végétation). An. Inst. Sup. Agron. 44: 5773.

Djema, A. \& Messaoudène, M. 2009. The Algerian forest: current situation and prospects. In: Palahi, M., Birot, Y., Bravo, F. \& Gorriz, E. (Eds.). Modelling, valuing and managing Mediterranean forest ecosystems for non-timber godos and services. EFI Proc. 57: 17-28.

Dubuis, A. \& Simonneau, P. 1954. Contribution à l'étude de la végétation de la région d'Aïn Skrouna. Serv. Et. Scient., Gouv. Génér. Algérie, Alger.

Fennane, M. 1988. Phytosociologie des tétraclinaies marocaines. Bull. Inst. Sci. Rabat 12: 99-148.

Fennane, M. 2003. Inventaire des communautés végétales à l'aide du phytosociologue au Maroc. Phytosociological checklist of Morocco. Ecol. Medit. 29(1): 87-106.

Gadek, P.A., Alpers, D.L., Heslewood, M. \& Quinn, C.J. 2000. Relationships within Cupressaceae sensu lato: a combined morphological and molecular approach. Amer. J. Bot. 87: 1044-1057.

Géhu, J.M. \& Géhu-Franck, J. 1986. Donnés synsystématiques et synchorologiques sur la végétation du littoral tunisien de Bizerte á Gabes. 1. La végétation psammophile. Doc. Phytosociol. N.S. 10(II): 127155.

Géhu, J.M., Kaabèche, M. \& Gharzouli, R. 1992. Observations phytosociologiques sur le littoral kabyle, de Béjaia à Jijel. Doc. Phytosociol. N.S. 14: 305-322.

Géhu, J.M., Kaabèche, M. \& Gharzouli, R. 1994a. Observations phytosociologiques dans le Nord-est de l'Algérie. Phytocoenologia 24: 369-382.

Géhu, J.M., Kaabèche, M. \& Gharzouli, R. 1994b. L'aulnaie glutineuse de la région d'El Kala, Annaba (Algérie): une remarquable irradiation biogéographique européenne en Afrique du Nord. Fitosociologia 27: 67-71.

Géhu, J.M. \& Sadki, N. 1996 ('1995'). Remarques de phytosociologie et de synchorologie comparée sur le littoral algérois. Doc. Phytosociol. N.S. 15: 341-357.

Géhu, J.M., Meddour, R., Kaabèche, M. \& Sadki, N. 1998. Typologie hiérarchisée des principales unites phytosociologiques d'Algérie ou diversité des habitats biologiques d'Algérie. Annexe $n^{\circ} 4$ - Direction Générale de l'Environnement, Direction de la préservation de la biodiversité et des espaces naturels. FEM/PNUD, Alger/Bailleul. 
Gharzouli, R. 1989. Contribution à l'étude de la végétation de la chaîne des Babors. Mem. Doc. (ined.). Inst. Nat. Ens. Sup. Biol., Sétif.

Gharzouli, R. 2007. Flore et végétation de la Kabylie des Babors: étude floristique et phytosociologique des groupements forestiers et post-forestiers des djebels Takoucht, Adrar Ou-Mellal, Tababort et Babor. Mem. Doc. (ined.). Univ. Sétif.

Guinochet, M. 1980. Essai sur quelques syntaxons des Cisto-Rosmarinetea et des Quercetea ilicis d'Algérie et de Tunisie. Phytocoenologia 7: 436-466.

Hadjadj-Aoul, S. 1988. Analyse phytoécologique du thuya de Berbérie (Tetraclinis articulata (Vahl) Masters) en Oranie. Mem. Doc. (ined.). Univ. Oran.

Hadjadj, S. 1991. Les peuplements de Tetraclinis articulata sur le littoral d'Oran (Algérie). Ecol. Medit. 17: 63-78.

Hadjadj-Aoul, S. 1993. Flore et végétation des gorges de la Chiffa (Alger). Rôle et place de Tetraclinis articulata. Bull. Soc. Linn. Provence 44: 89-97.

Hadjadj-Aoul, S. 1995. Les peuplements de Thuya de Berbérie en Algérie. Phytoécologie, syntaxonomie, potentialités sylvicoles. Mem. Doc. (ined.). Univ. Aix-Marseille III.

Hadjadj-Aoul, S. \& Loisel, R. 1999. Syntaxonomie des peuplements algériens du Thuya de Berbérie (Tetraclinis articulata (Vahl) Masters). Les peuplements forestiers et préforestiers. Doc. Phytosociol. N.S. 19: 229-285.

Iboukassene, S. 2008. Dynamique de la végétation des forêts à Quercus suber anthropisées du Nord-Est de l'Algérie (Parc National d'El-Kala). Mem. Doc. (ined.). Univ. Cathol. Louvain, Louvain-la-Neuve.

Jørgensen, S.E. (Ed.). 2009. Ecosystem ecology. Academic Press, Amsterdam.

Julve, P. 1993. Synopsis phytosociologique de la France (communautés de plantes vasculaires). Lejeunia N.S. 140: 1-160.

Kaabèche, M. 1990. Les groupements végétaux de la région de Bou Saâda (Algérie). Contribution à la synsystématique des groupements steppiques du Maghreb. Mem. Doc. (ined.). Univ. Paris-Sud.

Kaabèche, M. 1995. Les forêts de pin d'Alep de l'Atlas saharien (Algérie). Essai de synthèse phytosociologique par application de techniques numériques d'analyse. Doc. Phytosociol. N.S. 15: 235-251.

Kaabèche, M., Gharzouli, R. \& Géhu, J.M. 1995 ('1994'). Phytosociologie et typologie des habitats de la haute vallée de l'oued Bou-Sellam (Sétif, Algérie). Coll. Phytosociol. 23: 531-557.

Kaabèche, M., Gharzouli, R. \& Géhu, J.M. 1998. Les communautés à Euphorbia dendroides L. d'Algérie. Syntaxonomie, synécologie et synchorologie. Itinera Geobot. 11: 139-158.

Kadi-Hanifi, A. 1998. L'alfa en Algérie: syntaxonomie, relations milieu-végétation, dynamique et perspectives d'avenir. Mem. Doc. (ined.). Univ. Bab Ezzouar, Alger.

Kadik, B. 1983. Contribution à l'étude du pin d'Alep (Pinus halepensis Mill.) en Algérie: écologie, dendrométrie et morphologie. Offices des Publications Universitaires, Alger.

Kadik, L. 2005. Etude phytosociologique et phytoécologique des formations à pin d'Alep (Pinus halepensis Mill.) de l'étage bioclimatique semi-aride algérien. Mem. Doc. (ined.). Univ. Bab Ezzouar, Alger.

Khelifi, H. 1987. Contribution à l'étude phytoécologique et phytosociologique des formations à chêne liège dans le Nord-est algérien. Mem. Doc. (ined.). Univ. Bab Ezzouar, Alger.

Khelifi, H. 2008. L'écosystème côtier en Algérie: phytosociologie, symphytosociologie et intérêt patrimonial des végétations littorales du secteur algérois. Mem. Doc. (ined.). Inst. Nat. Agron., Alger.

Khelifi, H. \& Sadki, N. 1995 ('1994'). Esquisse géobotanique des régions de Collo, Skikda, et Annaba (Nord-Est algérien). Coll. Phytosociol. 23: 594-615.

Khelifi, H., Siab-Farsi, B. \& Khadid, Y. 2014. Essai de synthèse phytosociologique sur les groupements psammophiles du littoral en Algérie. Doc. Phytosociol., Sér. 3, 1: 247-257.

Kolai, L. 1991. La sapinière à Abies numidica dans le Mont Babor: phytosociologie et production. In: Ducrey, M. \& Oswald, H. (Eds.), Sémin. Intern. sur les sapins méditerranéens. Pp. 183-193. INRA, Avignon.

Laribi, M. 2000. Contribution à l'étude phytosociologique des formations caducifoliées à Quercus canariensis Willd. et Quercus afares Pomel du massif d'Ath Ghobri-Akfadou (Grande Kabylie). Mem. Doc. (ined.). Univ. Tizi Ouzou.

Laribi, M., Derridj, A. \& Acherar, M. 2008. Phytosociologie de la forêt caducifoliée à chêne zéen (Quercus canariensis Willd.) dans le massif d'Ath Ghobri-Akfadou (Grande Kabylie, Algérie). Fitosociologia 45(2): 77-92. 
Lemouissi, S. 2014. Approche phytosociologique de la végétation dans le massif forestier de Chettabah (Constantine). Mem. Doc. (ined.). Univ. Constantine 1.

Loisel, R. 1971. Séries de végétation propres, en Provence, aux massifs des Maures et de l'Estérel (ripisylves exclues). Bull. Soc. Bot. France 118: 203-236.

Loisel, R., 1976. La végétation de l'étage méditerranéen dans le sud-est continental français. Mem. Doc. (ined.). Univ. Aix-Marseille III.

Maire, R. 1926. Carte phytogéographique de l'Algérie et de la Tunisie. Notice Gouvern. Gén. Algér., Service cartographique, Alger.

Meddour, R. 1993. Analyse phytosociologique de la chênaie caducifoliée mixte de Tala Kitane (Akfadou, Algérie). Ecol. Medit. 19(3-4): 43-51.

Meddour, R. 1994a. Contribution à l'étude phytosociologique de la portion centro-orientale du parc national de Chréa. Essai d'interprétation synthétique des étages et des séries de végétation de l'Atlas Blidéen. Mem. Doc. (ined.). Inst. Nat. Agron., Alger.

Meddour, R. 1994b. La cédraie de l'Atlas blidéen (Algérie). Valeur bioclimatique, syntaxonomique et dynamique. Ann. Rech. For. Maroc, N. Spéc. 27: 105-127.

Meddour, R. 1998. Le fourré présylvatique à Crataegus monogyna de l'Atlas blidéen (Algérie). Doc. Phytosociol. N.S. 18: 23-31.

Meddour, R. 1999. La formation caducifoliée présylvatique à Ulmus procera et Acer monspessulanum du Djurdjura nord-occidental (Algérie). Doc. Phytosociol. N.S. 19: 447-452.

Meddour, R. 2001. Impact anthropozoïque sur la structure et la composition floristique des phytocénoses forestières montagnardes de l'Atlas tellien. In: Kerdoun, A., Larouk, M.E.H. \& Sahli, M. (Eds.). Impacts sur l'écosystème et stratégies de protection. Pp. 157-166. LERMM, Univ. Mentouri Constantine.

Meddour, R. 2002. Bioclimats, étages et séries de végétation de l'Atlas blidéen (Algérie). Phytocoenologia 32: $101-128$.

Meddour, R. 2010. Bioclimatologie, phytogéographie et phytosociologie en Algérie. Exemple des groupements forestiers et préforestiers de la Kabylie djurdjuréenne. Mem. Doc. (ined.). Univ. Tizi Ouzou.

Meddour, R. \& Géhu, J.M. 1998. Observations sur le synsystème des communautés forestières et préforestières en Algérie. Doc. Phytosociol. N.S. 18: 33-47.

Meddour, R. \& Laribi, M. 1999. La ripisylve à Alnus glutinosa (L.) Gaertn. de l'Akfadou (Grande Kabylie, Algérie). Doc. Phytosociol. N.S. 19: 385-400.

Meddour, R., Meddour-Sahar, O., Derridj, A. \& Géhu, J.M. 2010. Synopsis des groupements végétaux forestiers et préforestiers de la Kabylie djurdjuréenne (Algérie). Rev. For. France 62: 295-308.

Medjahdi, B. 2010. Réponse de la végétation du littoral Oranais aux perturbations: cas des monts des Trara (nord-ouest de l'Algérie). Mem. Doc. (ined.). Univ. Tlemcen.

Mesli, K. 2001. Contribution à une étude syntaxonomique et écologique des matorrals de la region de Tlemcen. Mem. Doc. (ined.). Univ. Tlemcen.

Meziani, K. 1984. Le cordon dunaire du littoral de la région de Mostaganem. Mem. Doc. (inéd.). Univ. Aix-Marseille III.

Miara, M.D. 2011. Contribution à l'étude de la végétation du massif de Guezoul (Tiaret). Mem. Doc. (inéd.). Univ. Oran.

Miara, M.D., Hadjadj-Aoul, S. \& Ait Hammou, M. 2012. Analyse phytoécologique et syntaxonomique des groupements végétaux dans le Massif de Guezoul, Tiaret (NO Algérie). Bull. Soc. Bot. Centre-Ouest N.S. 43: 279-316.

Monjauze, A. 1958. Le groupement à micocoulier (Celtis australis L.) en Algérie. Mém. Soc. Hist. Nat. Afr. Nord N.S. 2: 1-75.

Mucina, L., Bültmann, H., Dierßen, K., Theurillat, J.-P., Raus, T., Čarni, A., Šumberová, K., Willner, W., Dengler, J., Gavilán García, R., Chytrý, M., Hájek, M., Di Pietro, R., Iakushenko, D., Pallas, J., Daniëls, F.J.A., Bergmeier, E., Santos Guerra, A., Ermakov, N., Valachovič, M., Schaminée, J.H.J., Lysenko, T., Didukh, Y.P., Pignatti, S., Rodwell, J.S., Capelo, J., Weber, H.E., Solomeshch, A., Dimopoulos, P., Aguiar, C., Hennekens, S.M. \& Tichý, L. 2016. Vegetation of Europe: Hierarchical floristic classification system of vascular plant, bryophyte, lichen, and algal communities. Appl. Veg. Sci. 19, Suppl. 1: 3-264. doi: 10.1111 /avsc. 12257

Nègre, R. 1964. Carte au 1/50 000 de Tipasa. Mém. Soc. Hist. Nat. Afr. Nord N.S. 8: 1-68.

Pignatti, S. 1952. Note fitosociologiche su alcune associazioni alofile del litorale tunisino. Boll. Soc. Vent. St. Nat. Mus. Civ., St. Nat. 6(1): 77-94. 
Quézel, P. 1956. Contribution à l'étude des forêts de chênes à feuilles caduques d'Algérie. Mém. Soc. Hist. Nat. Afr. Nord N.S. 1: 1-57.

Quézel, P. \& Barbero, M. 1981. Contribution à l'étude des formations présteppiques à genévriers au Maroc. Bol. Soc. Brot., Sér. 2, 53: 1137-1160.

Quézel, P. \& Barbero, M. 1986. Aperçu syntaxonomique sur la connaissance actuelle de la classe des Quercetea ilicis au Maroc. Ecol. Medit. 12(3-4): 105-112.

Quézel, P., Barbero, M., Benabid, A., Loisel, R. \& Rivas-Martínez, S. 1988. Contribution à l'étude des groupements préforestiers et des matorrals rifains. Ecol. Medit. 14(1-2): 77-122.

Quézel, P. \& Barbero, M. 1989. Les formations à genévriers rampants du Djurdjura (Algérie). Leur signification écologique, dynamique et syntaxonomique dans une approche globale des cédraies kabyles. Lazaroa 11: 85-99.

Quézel, P. \& Médail, F. 2003a. Ecologie et biogéographie des forêts du bassin méditerranéeen. Elsevier, Paris.

Quézel, P. \& Médail, F. 2003b. Valeur phytoécologique et biologique des ripisylves méditerranéennes. Forêt Médit. 24: 231-248.

Rebbas, K. 2002. Contribution à l'étude de la végétation du parc national Gouraya (Béjaïa, Algérie): étude phytosociologique. Mem. Doc. (ined.). Univ. Sétif.

Rebbas, K., Véla, E., Gharzouli, R., Djellouli, Y., Alatou, D. \& Gachet, S. 2011. Caractérisation phytosociologique de la végétation du parc national de Gouraya (Béjaïa, Algérie). Rev. Écol. (Terre Vie) 66: 267-289.

Rivas-Martínez, S. 1975. La vegetación de la classe Quercetea ilicis en España et Portugal. An. Inst. Bot. Cavanilles 31: 205-259.

Rivas-Martínez, S. \& Rivas Goday, S. 1975. Schéma syntaxonomique de la classe Quercetea ilicis dans la Péninsule Ibérique. Coll. Intern. CNRS 235: 431-445.

Rivas-Martínez, S., Costa, M. \& Izco, J. 1986. Sintaxonomía de la clase Quercetea ilicis en el Mediterráneo occidental. Notiz. Fitosociol. 19: 71-98.

Rivas-Martínez, S., Fernández-González, F. \& Loidi, J. 1999. Checklist of plant communities of Iberian Peninsula, Balearic and Canary Islands to sublevel. Itinera Geobot. 13: 353-451.

Rivas-Martínez, S., Fernández-González, F., Loidi, J., Lousã, M. \& Penas, A. 2001. Syntaxonomical Checklist of vascular plant communities of Spain and Portugal to association level. Itinera Geobot. 14: 5-341.

Rivas-Martínez, S., Díaz, T.E., Fernández-González, F., Izco, J., Loidi, J., Lousã, M. \& Penas, A. 2002. Vascular plant communities of Spain and Portugal. Addenda to the syntaxonomical checklist of 2001. Itinera Geobot. 15: 433-922.

Rivas-Martínez, S. y coautores 2011. Mapa de series, geoseries y geopermaseries de vegetación de España [memoria del mapa de vegetación potencial de España]. Parte II. Itinera Geobot., N.S. 18(1): 5-424.

Sadki, N. 1988. Contribution à l'étude des groupements à olivier et lentisque de la région d'Annaba (Nordest algérien). Essai phytosociologique. Mem. Doc. (ined.). Univ. Bab Ezzouar, Alger.

Sadki, N. 1995. Etude des groupements à olivier et lentisque de la région d'Annaba (Nord-est algérien). Essai phytosociologique. Doc. Phytosociol. N.S. 15: 253-271.

Salamani, M. 1990. Contribution à l'étude de la végétation actuelle et passée (Holocène) du massif de l'Akfadou (Grande Kabylie). Mem. Doc. (ined.). Univ. Bab Ezzouar, Alger.

Serra, G., Loddo, S. \& Bacchetta, G. 2002. Relationship between soils, climate and vegetation in Quercus suber L. formations of the Sulcis-Iglesiente (southern Sardinia, Italy). Options Medit., Ser. A, 50: 127-133.

Siab-Farsi, B., Khelifi, H. \& Kadid, Y. 2014. Les maquis littoraux de la région algéroise: syntaxonomie et phytodiversité. Doc. Phytosociol., Sér. 3, 1: 419-425.

Tchou, Y.T. 1949. Études écologiques et phytosociologiques sur les forêts riveraines du Bas-Languedoc. Vegetatio 1: 93-128, 217-257 \& 347-384.

Theurillat, J.-P., Aeschimann, D., Küpfer, P. \& Spichiger, R. 1995. The higher vegetation units of the Alps. Coll. Phytosociol. 23: 189-239.

Thomas, J.P. 1969. Ecologie et dynamisme de la végétation de la dune littorale dans la région de Djidjelli. Bull. Soc. Hist. Nat. Afr. Nord. 59: 1-63.

Timbal, J. 1970. Note sur la presence en Tunisie de Rhamnus frangula L. Bull. Soc. Bot. France 117: 293296.

Toubal, O. 1986. Phytoécologie, biogéographie et dynamique des principaux groupements du massif de l’Edough (Algérie nord-orientale). Cartographie au 1/25 000. Mem. Doc. (ined.). Univ. Grenoble. 
Toubal, O. 1998. Le Prunetum aviae, le Genistetum numidicae et le Chamaeropetum humilii trois associations qui caractérisent la végétation numidienne (Edough, NE Algérie). Itinera Geobot. 11: 213-226.

Toubal, O. \& Toubal, A. 1996a. L'Euphorbietum dendroidis, faciès rupicole de l'Oleo-Lentiscetum sur substrat rocheux du littoral, micaschistes et calcaires métamorphiques (Cap de Garde, Oued Begrat, NE algérien). Coll. Phytosociol. 24: 755-769.

Toubal, O. \& Toubal, A. 1996b. Diversité et dynamisme de la végétation de l'Edough (NE Algérie). Relation avec la lithologie. Coll. Phytosociol. 24: 585-599.

Weber, H.E., Moravec, J. \& Theurillat, J.P. 2000. International Code of Phytosociological Nomenclature. 3rd ed. J. Veg. Sci. 11: 739-768.

Westhoff, V. 1967. Problems and use of structure in the classification of vegetation. The diagnostic evaluation of structure in the Braun-Blanquet system. Acta Bot. Neerl. 15: 495-511.

Wojterski, T. 1988. Guide de l'excursion internationale de phytosociologie. Algérie du Nord. Glotze, Göttingen.

Wojterski, T. 1990. Degradation stages of the oak forests in the area of Algiers. Vegetatio 87: 135-143.

Wojterski, T. \& Bensettiti, F. 1988. Anthropogen bedingte Veränderungen der Auenwälder in Nordalgerien. Flora 180: 93-100.

Yahi, N. 1995. Contribution à l'étude phytosociologique des formations à Cèdre Cedrus atlantica Manetti de l'Atlas tellien (Babors, Djurdjura, Ouarsenis). Mem. Doc. (ined.). Univ. Bab Ezzouar, Alger.

Yahi, N. 2007. Les cédraies d'Algérie: phytoécologie, phytosociologie, dynamique et conservation des peuplements. Mem. Doc. (ined.). Univ. Bab Ezzouar, Alger.

Yahi, N., Mediouni, K. \& Géhu, J.-M. 1999. Syntaxonomie des groupements à Cèdre Cedrus atlantica Manetti d'Algérie. Doc. Phytosociol. N.S. 19: 417-431.

Yahi, N. \& Mediouni, K. 2000 ('1997'). Phytosociologie des groupements à cèdre (Cedrus atlantica Manetti) du massif de Téniet el Had (Algérie). Coll. Phytosociol. 27: 479-490.

Yang, Z.-Y., Ran, J.-H. \& Wang, X.-Q. 2012. Three genome-based phylogeny of Cupressaceae s.1.: Further evidence for the evolution of gymnosperms and Southern Hemisphere biogeography. Mol. Phylogen. Evol. 64: 452-470.

Zaffran, J. 1960. Les formations à Juniperus phoenicea L. du littoral algérien. Bull. Soc. Hist. Nat. Afr. Nord 51: 303-338.

Zeraia, L. 1981. Essai d'interprétation des données écologiques, phénologiques et de production subéro-ligneuse dans les forêts de chêne liège de Provence cristalline et d'Algérie. Mem. Doc. (ined.). Univ. Aix-Marseille III.

Appendix 1: List of new syntaxa described (or validated) in this paper as well as associations awaiting effective publication or validation.

\section{New Order}

Ephedro majoris-Juniperetalia phoeniceae Quézel \& Barbero ex Meddour, Meddour-Sahar, Zeraia \& Mucina 2017

\section{New Alliances}

Abietion maroccano-numidicae Mucina \& Meddour in Meddour, Meddour-Sahar, Zeraia \& Mucina 2017 Calicotomo intermediae-Quercion cocciferae Dahmani-Megrerouche \& Loisel ex Meddour, MeddourSahar, Zeraia \& Mucina 2017

Campanulo alatae-Alnion glutinosae Meddour, Meddour-Sahar, Zeraia \& Mucina 2017

Clematido cirrhosae-Populion albae Bensettiti \& Lacoste ex Meddour, Meddour-Sahar, Zeraia \& Mucina 2017 
Genisto tricuspidatae-Calicotomion spinosi Dahmani-Megrerouche \& Loisel ex Meddour, Meddour-Sahar, Zeraia \& Mucina 2017

Lamio garganici-Cedrion atlanticae Abdessemed in Meddour, Meddour-Sahar, Zeraia \& Mucina 2017

Lonicero implexae-Quercion cocciferae Meddour, Meddour-Sahar, Zeraia \& Mucina 2017

Loto dorycnium-Quercion rotundifoliae Djebaïli in Meddour, Meddour-Sahar, Zeraia \& Mucina 2017

Plagio maghrebini-Quercion canariensis Meddour, Meddour-Sahar, Zeraia \& Mucina 2017

Salici pedicellatae-Fraxinion angustifoliae Meddour, Meddour-Sahar, Zeraia \& Mucina 2017

Scrophulario laevigatae-Acerion obtusati Meddour, Meddour-Sahar, Zeraia \& Mucina 2017

Tamo communis-Salicion atrocinereae de Foucault \& Julve ex Mucina \& Meddour in Meddour, Meddour-

Sahar, Zeraia \& Mucina 2017

\section{New Associations}

Calicotomo intermediae-Quercetum rotundifoliae Dahmani-Megrerouche \& Loisel ex Meddour, MeddourSahar, Zeraia \& Mucina 2017

Calicotomo spinosae-Quercetum rotundifoliae Dahmani-Megrerouche \& Loisel ex Meddour, MeddourSahar, Zeraia \& Mucina 2017

Cisto salviifolii-Quercetum rotundifoliae Dahmani-Megrerouche \& Loisel ex Meddour, Meddour-Sahar, Zeraia \& Mucina 2017

Coronillo valentinae-Quercetum Guinochet ex Meddour in Meddour, Meddour-Sahar, Zeraia \& Mucina 2017

Equiseto maximi-Fraxinetum angustifoliae Bensettiti \& Lacoste ex Meddour, Meddour-Sahar, Zeraia \& Mucina 2017

Genisto quadriflorae-Pinetum halepensis Meddour, Meddour-Sahar, Zeraia \& Mucina 2017

Loto dorycnium-Pinetum halepensis Djebaïli, Meddour \& Mucina in Meddour, Meddour-Sahar, Zeraia \& Mucina 2017

Nerio oleandri-Tamaricetum africanae Kaabèche, Gharzouli \& Géhu ex ex Mucina \& Meddour in Meddour, Meddour-Sahar, Zeraia \& Mucina 2017

Plagio maghrebini-Quercetum canariensis Laribi in Meddour ex Meddour, Meddour-Sahar, Zeraia \& Mucina 2017

Quercetum balloto-broteroi Meddour, Meddour-Sahar, Zeraia \& Mucina 2017

Ranunculo aurasiaci-Cedretum atlanticae Meddour, Meddour-Sahar, Zeraia \& Mucina 2017

Scrophulario laevigatae-Aceretum obtusati Wojterski ex Meddour, Meddour-Sahar, Zeraia \& Mucina 2017

Smilaco asperae-Pistacietum lentisci (Nègre 1964) Meddour, Meddour-Sahar, Zeraia \& Mucina 2017

Viburno tini-Quercetum canariensis Meddour, Meddour-Sahar, Zeraia \& Mucina 2017

Viti viniferae-Alnetum glutinosae Meddour, Meddour-Sahar, Zeraia \& Mucina 2017

\section{Associations awaiting effective publication}

Aceri monspessulani-Smyrnietum olusatri Abdessemed 1981 nom. inval. (Art. 1) Ampelodesmo mauritanicae-Quercetum cocciferae Kadik 2005 nom. inval. (Art. 1) Arisaro vulgaris-Pinetum halepensis Brakchi 1998 nom. inval. (Art. 1)

Berberido hispanicae-Cedretum atlanticae Benabid 1994 nom. inval. (Art. 1)

Buxo sempervirentis-Cerastietum gibraltarici Gharzouli 1989 nom. inval. (Art. 1)

Cedro atlanticae-Aceretum monspessulani Azira-Atroune 2001 nom. inval. (Art. 1)

Cotyledoni brevifoliae-Aceretum obtusati Azira-Atroune 2001 nom. inval. (Art. 1)

Cystopterido fragilis-Aceretum obtusati Azira-Atroune 2001 nom. inval. (Art. 1)

Erico arboreae-Pinetum halepensis Brakchi 1998 nom. inval. (Art. 1)

Erico arboreae-Tetraclinetum articulatae Hadjadj-Aoul 1988 nom. inval. (Art. 1)

Festuco triflorae-Quercetum suberis Meddour 2010 nom. inval. (Art. 1)

Genisto ulicinae-Quercetum cocciferae Djaboub 2008 nom. inval. (Art. 1)

Junipero hemisphaericae-Cedretum atlanticae Meddour 2010 nom. inval. (Art. 1)

Linario rubrifoliae-Aceretum campestris Azira-Atroune 2001 nom. inval. (Art. 1)

Lonicero etruscae-Ilicetum aquifolii Abdessemed 1981 nom. inval. (Art. 1)

Physospermo verticillati-Cedretum atlanticae Meddour 2010 nom. inval. (Art. 1) 
Pistacio lentisci-Calicotometum spinosae Boussouf 2004 nom. inval. (Art. 1)

Potentillo micranthae-Cedretum atlanticae Meddour 2010 nom. inval. (Art. 1)

Prunetum avii Toubal 1998 nom. inval. (Art. 1)

Ptilostemono riphaei-Quercetum rotundifoliae Meddour 2010 nom. inval. (Art. 1)

Saturejo baborensis-Cedretum atlanticae Gharzouli 2007 nom. inval. (Art. 1)

Sileno atlanticae-Cedretum atlanticae Meddour 2010 nom. inval. (Art. 1)

Sorbo ariae-Cedretum atlanticae Gharzouli 2007 nom. inval. (Art. 1)

Tamo communis-Crataegetum monogynae Meddour 1998 nom. inval. (Art. 1)

Telino linifoliae-Quercetum suberis Zeraia 1981 nom. inval. (Art. 1)

Tetraclini articulatae-Lavanduletum dentatae Dahmani 1984 nom. inval. (Art. 1)

\section{Associations awaiting validation}

Biscutello raphanifoliae-Cedretum atlanticae Yahi, Médiouni \& Géhu 1999 nom. inval. (Art. 2b)

Bupleuro fruticosi-Euphorbietum dendroidis Géhu, Kaabèche \& Gharzouli 1992 nom. inval. (Art. 5)

Buxo sempervirentis-Abietetum numidicae Yahi, Médiouni \& Géhu 1999 nom. inval. (Art. 2b)

Cedro atlanticae-Quercetum rotundifoliae Abdessemed 1984 nom. inval. (Art. 2b)

Cerastio atlantici-Cedretum atlanticae Yahi in Yahi, Médiouni \& Géhu1999 nom. inval. (Art. 2b)

Chamaeropo humilis-Asparagetum altissimi Guinochet 1980 nom. inval. (Art. 5)

Clematidi cirrhosae-Juniperetum lyciae Barbero, Quézel \& Rivas-Martínez 1981 nom. inval. (Art. 2b)

Cynosuro peltierii-Quercetum afaredis Laribi in Laribi, Derridj \& Acherar 2008 nom. inval. (Arts. 2b \& 5)

Cytiso villosi-Quercetum rotundifoliae Dahmani-Megrerouche \& Loisel 2003 nom. inval. (Art. 5)

Euphorbio bivonae-Rhoetum tripartitae Siab-Farsi, Khelifi \& Kadid 2014 nom. inval. (Art. 5)

Festuco triflorae-Quercetum rotundifoliae Dahmani-Megrerouche 1996 nom. inval. (Art. 2b)

Junipero turbinatae-Quercetum rotundifoliae Dahmani-Megrerouche \& Loisel 2003 nom. inval. (Art. 5)

Lauro nobilis-Celtidetum australis Bensettiti \& Lacoste 1999 nom. inval. (Art. 2b)

Phillyreo latifoliae-Pistacietum lentisci Benabid 1982 nom. inval. (Art. 5)

Phlomido bovei-Quercetum rotundifoliae Zeraia in Meddour 2002 nom. inval. (Art. 2b)

Pistacio lentisci-Quercetum rotundifoliae Dahmani-Megrerouche \& Loisel 2003 nom. inval. (Art. 5)

Pistacio lentisci-Quercetum suberis Khelifi \& Sadki 1985 nom. inval. (Art. 5)

Pistacio terebinthi-Quercetum rotundifoliae Dahmani-Megrerouche \& Loisel 2003 nom. inval. (Art. 5)

Ranunculo spicati-Cedretum atlanticae Abdessemed in Dahmani-Megrerouche 1996 nom. inval. (Art. 2b)

Salici pedicellatae-Populetum nigrae Bensettiti \& Lacoste 1999 nom. inval. (Arts. 2b \& 5)

Senecioni gallerandiani-Cedretum atlanticae Yahi in Yahi, Médiouni \& Géhu 1999 nom. inval. (Art. 2b)

\section{Awaiting new name}

Junipero oxycedri-Quercetum cocciferae Hadjadj-Aoul \& Loisel 1999 nom. illeg. (Art. 31) 